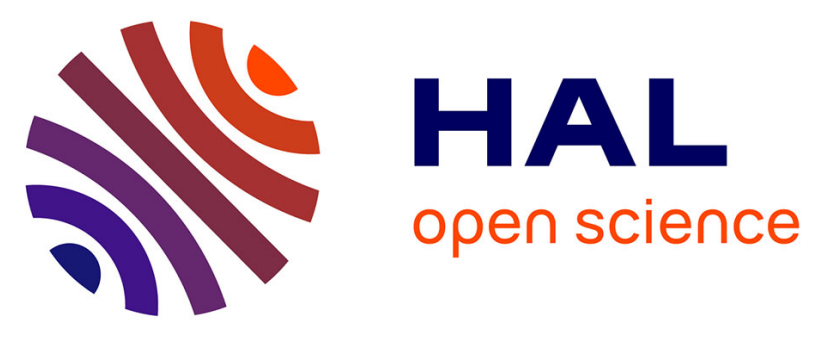

\title{
Implementing Cyclopentane Hydrates Phase Equilibrium Data and Simulations in Brine Solutions
}

Son Ho-Van, Baptiste Bouillot, Jérôme Douzet, Saheb Maghsoodloo Babakhani, Jean-Michel Herri

\section{- To cite this version:}

Son Ho-Van, Baptiste Bouillot, Jérôme Douzet, Saheb Maghsoodloo Babakhani, Jean-Michel Herri. Implementing Cyclopentane Hydrates Phase Equilibrium Data and Simulations in Brine Solutions. Industrial and engineering chemistry research, 2018, 57 (43), pp.14774 à 14783. 10.1021/acs.iecr.8b02796 . hal-01987858

\section{HAL Id: hal-01987858 https://hal.science/hal-01987858}

Submitted on 21 Jan 2019

HAL is a multi-disciplinary open access archive for the deposit and dissemination of scientific research documents, whether they are published or not. The documents may come from teaching and research institutions in France or abroad, or from public or private research centers.
L'archive ouverte pluridisciplinaire HAL, est destinée au dépôt et à la diffusion de documents scientifiques de niveau recherche, publiés ou non, émanant des établissements d'enseignement et de recherche français ou étrangers, des laboratoires publics ou privés. 


\title{
Implementing Cyclopentane Hydrates Phase Equilibrium Data and Simulations in Brine Solutions
}

\author{
Son Ho-Van ${ }^{1,2}$, Baptiste Bouillot ${ }^{1} *$, Jérôme Douzet ${ }^{1}$, Saheb Maghsoodloo Babakhani ${ }^{1}$, \\ Jean-Michel Herri ${ }^{1}$ \\ ${ }^{1}$ Ecole Nationale Supérieure des Mines de Saint-Etienne, SPIN, CNRS 5307, LGF, F- \\ 42023, Saint-Etienne, France \\ ${ }^{2}$ Oil Refinery and Petrochemistry Department, Hanoi University of Mining and Geology, \\ Duc Thang, Bac Tu Liem, Hanoi, Vietnam \\ *Corresponding authors: son.ho-van@emse.fr (Son Ho-Van ) and bouillot@emse.fr
}

(Baptiste Bouillot)

Keywords: Cyclopentane Hydrates; Phase Equilibrium; Brine; Experimental; Modelling.

\begin{abstract}
Cyclopentane hydrates-based salt removal is considered to be a possible promising technology for desalination. In order to optimize such processes, phase equilibrium data of Cyclopentane Hydrates (CPH) in saline solutions are crucial. Lamentably, these data sets are still incomplete. Therefore, earlier we published a limited experimental and modeling study on $\mathrm{CPH}$ equilibrium with some salts present.

This study extends experimental equilibrium to four more common brine systems: $\mathrm{Na}_{2} \mathrm{SO}_{4}$, $\mathrm{MgCl}_{2}, \mathrm{MgCl}_{2}-\mathrm{NaCl}$, or $\mathrm{MgCl}_{2}-\mathrm{NaCl}-\mathrm{KCl}$ at various salt concentrations. Importantly, four thermodynamic approaches: the Standard Freezing Point Depression equation based (SFPD), HuLee-Sum (HLS) correlation, and the two van der Waals and Platteuw-based Kihara and ActivityBased Occupancy Correlation (ABOC) methods, are compared to this new set of experimental data. Results show that simulations agree adequately with measured data. Nonetheless, the ABOC method is the best model to reproduce rapid and consistent equilibrium data of $\mathrm{CPH}$ in brine, whatever the electrolytes involved.
\end{abstract}

\section{Introduction}

Clathrate hydrates are non-stoichiometric ice-like crystalline compounds formed by combination of a lattice of water molecules, and guest molecules. These guests are small molecules, capable to fit into the lattice cavities, such as $\mathrm{CO}_{2}, \mathrm{CH}_{4}, \mathrm{~N}_{2}$, Cyclopentane, etc. ${ }^{1}$ Three main polymorphs of 
clathrate hydrate are well known as structures I (sI), II (sII), and H (sH), composed of a certain number of cavities formed by water molecules through a hydrogen bonding system. ${ }^{1}$

Clathrate hydrates present many prospective applications, such as gas separation, ${ }^{2,3}$ gas storage, air-conditioning, ${ }^{6-8}$ carbon dioxide capture, ${ }^{9,10}$ and desalination. ${ }^{1,11,12}$ Recently, hydrate-based desalination has attracted significant interest due to international fresh water increasing demand. $^{13-17}$

In hydrate-based desalination, solid salts and dissolved ions are excluded from hydrate crystals during crystallization. Hydrate crystals can then be separated from the aqueous solution using a solid-liquid filter. Fresh water and guest molecules can be isolated after hydrate dissociation. If the guest molecules are gaseous at standard conditions, or hydrophobic, they can easily be removed from fresh water. Afterward, they can be recycled into the desalination process.

Certainly, hydrate-based desalination method has been studied widely and intensively for many years (since the 1960s). ${ }^{13,15,18-25}$ Nevertheless, this technology is not ready for industrial scale use yet. As stated in the review work by Babu et al. ${ }^{16}$, there are still some challenges yet to overcome: high energy consumption issues, separating hydrate crystals from highly concentrated saltwater without impurities, and slow kinetics. Recently, He et al. ${ }^{15}$ suggested a new hydrate based desalination system using Liquefied Natural Gas (LNG) cold energy. Compared to multi-stage flash distillation (MSF), reverse osmosis (RO), and freezing desalination processes, this technology can be attractive since LNG cold energy replaces the external refrigeration cycle, and hence reduces the specific energy consumption. ${ }^{15}$ Obviously, this novel technology still requires a large and steady source of LNG cold energy. High-pressure reactor is also needed because propane is utilized to form hydrate.

Cyclopentane with water forms sII clathrate hydrates at around $7.1^{\circ} \mathrm{C}$ under atmospheric pressure. $^{1,26}$ Because of its capability to form clathrate hydrates under such mild conditions, cyclopentane hydrates $(\mathrm{CPH})$ is a promising candidate for water treatment applications, such as desalination. Recently, some authors have attempted to use CPH for desalination: Corak et al. ${ }^{27}$ (optimize the subcooling for CPH-based desalination), Han et al. ${ }^{28,29}$ (use post treatment methods: washing, centrifuging, and sweating to remove excessive brine from $\mathrm{CPH}$ crystals), Cai et al. ${ }^{30}$ (desalination by using cyclopentane methane binary hydrate), Lv at al. ${ }^{31}$ (optimize kinetic of CPH-based desalination conditions), $\mathrm{Xu}$ et al. ${ }^{17}$ (use a three-step separation method, including gravitational separation, filtration, and a washing step with a salt removal efficiency of $81 \%$ ). 
However, before this CPH-based desalination technique is commercially ready, some important issues such as kinetic, thermodynamic (phase equilibrium data), entrapped salt quantity, and salt removal efficiency remain. They must be comprehensively understood and optimized. Unfortunately, in terms of $\mathrm{CPH}$ thermodynamics in presence of salts, there are still few experimental data available in the literature. Therefore, we previously compiled and verified equilibrium temperatures of $\mathrm{CPH}$ in presence of $\mathrm{NaCl}, \mathrm{KCl}, \mathrm{NaCl}-\mathrm{KCl}$, or $\mathrm{CaCl}_{2}$. Moreover, three thermodynamic methods were applied to simulate them. ${ }^{26}$ Nonetheless, more phase equilibrium data in other salts are still required, and thermodynamic approaches still need to be compared to a wider range of experimental data.

Consequently, this effort extends experimental dissociation temperature to four other brine systems: $\mathrm{Na}_{2} \mathrm{SO}_{4}, \mathrm{MgCl}_{2}$, equi-weight mixture of $\mathrm{MgCl}_{2}-\mathrm{NaCl}$ and equi-weight mixture of $\mathrm{MgCl}_{2}-\mathrm{NaCl}-\mathrm{KCl}$ under wide-ranges of salt concentrations. Then, our three previously developed thermodynamic models based on the Standard Freezing Point Depression method, or the van der Waals and Platteuw approaches, are again compared to this new data set. Moreover, a brand new method, the Hu-Lee-Sum (HLS) correlation is considered.

\section{Experimental section}

\section{Chemicals}

All chemicals used in this work were provided by Sigma-Aldrich Company. A water purification system was utilized to produce high-purity water with a conductivity $\sigma \leq 0.055 \mu \mathrm{S} . \mathrm{cm}^{-1}$ and TOC (total organic carbon content) less than 5 ppm. Details of chemicals are listed in Table 1.

Table 1. Purity of initial material used

\begin{tabular}{ccccc}
\hline Material & $\begin{array}{c}\text { Chemical } \\
\text { formula }\end{array}$ & $\begin{array}{c}\text { Mol.weight } \\
\left(\mathrm{g} \cdot \mathrm{mol}^{-1}\right)\end{array}$ & $\begin{array}{c}\text { Solubility in water } \\
(\mathrm{g} / \mathrm{l})\end{array}$ & $\begin{array}{c}\text { Purity } \\
\% \mathrm{~mol}\end{array}$ \\
\hline Cyclopentane & $\mathrm{C}_{5} \mathrm{H}_{10}$ & 70.1 & $0.156\left(25^{\circ} \mathrm{C}\right)^{32}$ & $98.0 \%$ \\
Sodium chloride & $\mathrm{NaCl}$ & 58.4 & $360\left(20{ }^{\circ} \mathrm{C}\right)^{33}$ & $99.5 \%$ \\
Potassium chloride & $\mathrm{KCl}$ & 74.55 & $344\left(20^{\circ} \mathrm{C}\right)^{33}$ & $99.0 \%$ \\
Magnesium chloride & $\mathrm{MgCl}_{2}$ & 95.21 & $54.6\left(20^{\circ} \mathrm{C}\right)^{33}$ & $99.5 \%$ \\
Sodium sulfate & $\mathrm{Na}_{2} \mathrm{SO}_{4}$ & 142.04 & $19.5\left(20^{\circ} \mathrm{C}\right)^{33}$ & $99.5 \%$ \\
\hline
\end{tabular}




\section{Apparatus}

Experimental apparatus is detailed in Figure 1.

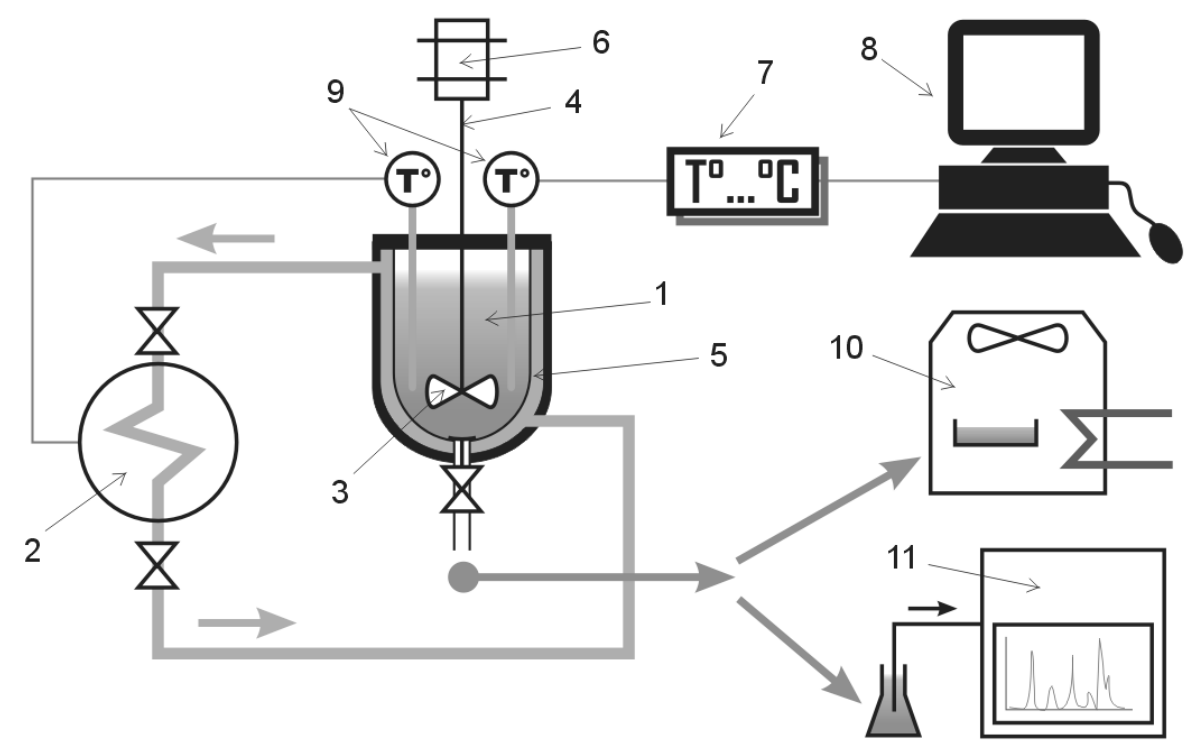

Figure 1. Diagram of the experimental apparatus

1-Vessel, 2-Chiller, 3-Impeller, 4-Agitator, 5-Cooling jacket, 6-Motor, 7-Temp transmitter, 8Computer, 9-Temperature probe, 10-Drying oven, 11-Ion chromatography.

A jacketed glass reactor (1) with a volume of one liter is provided by Verre Equipments (France). A chiller Ministat 240 (2) controls constantly and homogeneously the temperature of the solution, and has an operating temperature range of $\left[-45^{\circ} \mathrm{C}\right.$ to $\left.200{ }^{\circ} \mathrm{C}\right]$ with a stability of $\pm 0.02{ }^{\circ} \mathrm{C}$. The coolant used is a mixture of water and ethylene glycol (44\% mass). The solution inside the reactor is mixed by an impeller (3) powered by a motor (6). Two temperature probes (9) are utilized to monitor the aqueous mixture. A transmitter (7) transfers temperature data to a computer (8). LabVIEW observes and records the digital information throughout the course of experiments. To measure salt concentration of the solution, an ionic chromatography (Dionex DX-500 IC) system (11) was utilized. A drying oven (Binder) (10) was employed only for a second salt concentration measurement in the experiments with $\mathrm{Na}_{2} \mathrm{SO}_{4}$ solution.

\section{Procedure}

To determine the $\mathrm{CPH}$ dissociation temperatures, two procedures (quick and slow) are used as described in more detail in a previous article. ${ }^{26}$ 


\section{Quick procedure:}

In the reactor are introduced $500 \mathrm{~g}$ of pure water, a chosen amount of salt, and $114.38 \mathrm{~g}$ of $\mathrm{CP}$ (corresponding to the hydrate molar ratio water: $\mathrm{CP}=17: 1$ ). Then, the solution is cooled down to a temperature above the freezing-point of the salt solution. Crystallization is triggered by introducing grams of ice and a corresponding amount of salt to keep a constant salinity. After 1 2 hours of crystallization, the chiller is stopped. $\mathrm{CPH}$ then dissociates progressively. A sharp rise in temperature is observed when no hydrate is present in the reactor. This point corresponds presumably to the dissociation temperature of $\mathrm{CPH} .1 \mathrm{ml}$ and $5 \mathrm{ml}$ of brine solution are taken to measure salt concentration by ion chromatography and drying oven. This step is necessary to make sure all $\mathrm{CPH}$ have dissociated.

Of course, due to the high heating rate, this procedure is not quite accurate enough. However, it provides a stepping stone for the next procedure.

Note that, $\mathrm{MgCl}_{2}$ should form salt hydrates $\left(\mathrm{MgCl}_{2} \cdot 6 \mathrm{H}_{2} \mathrm{O}\right)$ after water evaporation at $60^{\circ} \mathrm{C}$ (set temperature of drying oven for all experiments). ${ }^{34,35}$ Therefore, the drying oven was not employed with solutions containing $\mathrm{MgCl}_{2}$ and ionic chromatography only was used instead.

\section{Slow procedure:}

A duplicate experiment is performed with a different dissociation procedure. After 1 - 2 hours of crystallization, chiller is functioned manually as follows:

The first heating step increases the temperature to a temperature of $4^{\circ} \mathrm{C}$ below the prior dissociation temperature recorded by the quick procedure. After stabilization, the temperature inside the reactor is increased at an increment of $0.1{ }^{\circ} \mathrm{C}$. Then, the temperature is remained constantly for at least 1 hour. If no significant $\mathrm{CPH}$ dissociation is observed after 1 hour, the temperature is augmented again by the same increment. This process is iterated until a small amount of hydrate is observed. The temperature is then kept steady for a longer time (12h-24h) to ensure that equilibrium is reached. The last step is required when hydrate is still present. The $\mathrm{CPH}$ dissociation temperature is recorded during next to last step as all three phases $(\mathrm{CP}, \mathrm{CPH}$ and brine) exist.

Images of the aqueous mixture are taken at every step. These images are then compared in order to determine the final step in which only two transparent phases of brine solution and CP can be observed as seen in the initial condition (pictures provided in the previous study ${ }^{26}$ ). 
Moreover, to make sure that there are no longer any $\mathrm{CPH}$ in the bulk at the final step, $1 \mathrm{ml}$ and 5 $\mathrm{ml}$ of brine solution are sampled to measure salt concentration.

\section{Experimental results}

All experimental results on phase equilibrium data of $\mathrm{CPH}$ following the slow dissociation procedure are provided in Table 2 and Figure 2. Note that the mass ratio $\mathrm{MgCl}_{2}: \mathrm{NaCl}$ is $1: 1$ in the equiweight mixture of $\mathrm{MgCl}_{2}-\mathrm{NaCl}$ and the mass ratio $\mathrm{MgCl}_{2}: \mathrm{NaCl}: \mathrm{KCl}$ is 1:1:1in the equiweight mixture of $\mathrm{MgCl}_{2}-\mathrm{NaCl}-\mathrm{KCl}$.

Our measure results show that the equilibrium temperatures obtained by the slow dissociation procedure $\left(\mathrm{T}^{\text {slow }}\right)$ are systematically lower than those provided by the quick dissociation procedure $\left(T^{\text {quick }}\right)$. This difference between the measured data from both procedures $\left(\Delta T=T^{\text {quick }}\right.$ $\mathrm{T}^{\text {slow }}$ ) ranges from $0.3^{\circ} \mathrm{C}$ up to $3.2^{\circ} \mathrm{C}$. We believe that quick dissociation procedure likely misses the total dissociation temperature, i.e. the equilibrium temperature, as stated by Ho-Van et al. ${ }^{26}$. Hence, the slower process furnishes more trustworthy and consistent equilibrium data than the quick.

Figure 2 indicates that the equilibrium temperatures considerably decrease with higher salt concentrations. Of course, electrolytes in solution affect significantly water activity, and hence $\mathrm{CPH}$ phase equilibria. Both phenomena of clustering and salting-out lower the equilibrium temperature of $\mathrm{CPH} .{ }^{1,26,36}$ Moreover, influence on equilibrium temperature is different for each salt. For instance, Table 2 reveals that the measured dissociation temperatures for $\mathrm{Na}_{2} \mathrm{SO}_{4}$ are higher than those for $\mathrm{MgCl}_{2}, \mathrm{MgCl}_{2}-\mathrm{NaCl}$, or $\mathrm{MgCl}_{2}-\mathrm{NaCl}-\mathrm{KCl}$. This can be attributed to the lower water activity and molality in presence of $\mathrm{Na}_{2} \mathrm{SO}_{4}$ compared to others salt at same concentrations (in \% mass) (see Appendix, Table A1). 
Table 2. Equilibrium temperatures ${ }^{\mathrm{a}}$ of $\mathrm{CPH}$ in the presence of $\mathrm{Na}_{2} \mathrm{SO}_{4}, \mathrm{MgCl}_{2}$, an equiweight mixture of $\mathrm{MgCl}_{2}-\mathrm{NaCl}$, or an equiweight mixture of $\mathrm{MgCl}_{2}-\mathrm{NaCl}-\mathrm{KCl}$ (slow dissociation procedure)

\begin{tabular}{|c|c|c|c|c|}
\hline $\begin{array}{c}\text { Salinity }^{\mathrm{b}, \mathrm{c}, \mathrm{d}} \text {,in } \\
\% \text { mass }\end{array}$ & in $\mathrm{Na}_{2} \mathrm{SO}_{4}\left({ }^{\circ} \mathrm{C}\right)$ & in $\mathrm{MgCl}_{2}\left({ }^{\circ} \mathrm{C}\right)$ & $\begin{array}{c}\text { in } \mathrm{MgCl}_{2}-\mathrm{NaCl} \\
\left({ }^{\circ} \mathrm{C}\right)\end{array}$ & $\begin{array}{c}\text { in } \mathrm{MgCl}_{2^{-}} \\
\mathrm{NaCl}-\mathrm{KCl},\left({ }^{\circ} \mathrm{C}\right)\end{array}$ \\
\hline 0 & 7.1 & 7.1 & 7.1 & 7.1 \\
\hline 1 & 6.7 & 6.7 & 6.5 & 6.7 \\
\hline 2 & 6.4 & 6.2 & 6.1 & 6.1 \\
\hline 3.5 & 6.0 & 5.2 & 5.1 & 5.2 \\
\hline 5 & 5.6 & 4.3 & 4.1 & 4.6 \\
\hline 6 & $5.3 *$ & - & - & - \\
\hline 8 & - & 2.1 & 2.3 & 2.7 \\
\hline 10 & - & 0 & 0.5 & 1.2 \\
\hline 12 & - & -2.2 & -1.6 & -0.2 \\
\hline 14 & - & -5.2 & -3.6 & -1.8 \\
\hline 16 & - & -8.7 & -5.8 & -3.8 \\
\hline 18 & - & -12.7 & -8.8 & -5.7 \\
\hline 20 & - & -17.6 & -12 & -8 \\
\hline 22 & - & - & -15.5 & -10.8 \\
\hline
\end{tabular}

* corresponds to eutectic point. ${ }^{\mathrm{a}}$ Uncertainty of the temperature measurements: $\pm 0.1{ }^{\circ} \mathrm{C} .{ }^{\mathrm{b}}$ Uncertainty due to weighing: $\pm 0.002 \%$ mass. ${ }^{\mathrm{c}}$ Uncertainty due to drying oven: $\pm 0.2 \%$ mass. ${ }^{\mathrm{d}}$ Relative uncertainty due to ion chromatography: $1.5 \%$ (see the supporting information from HoVan et al. ${ }^{26}$ for all uncertainty estimations). 


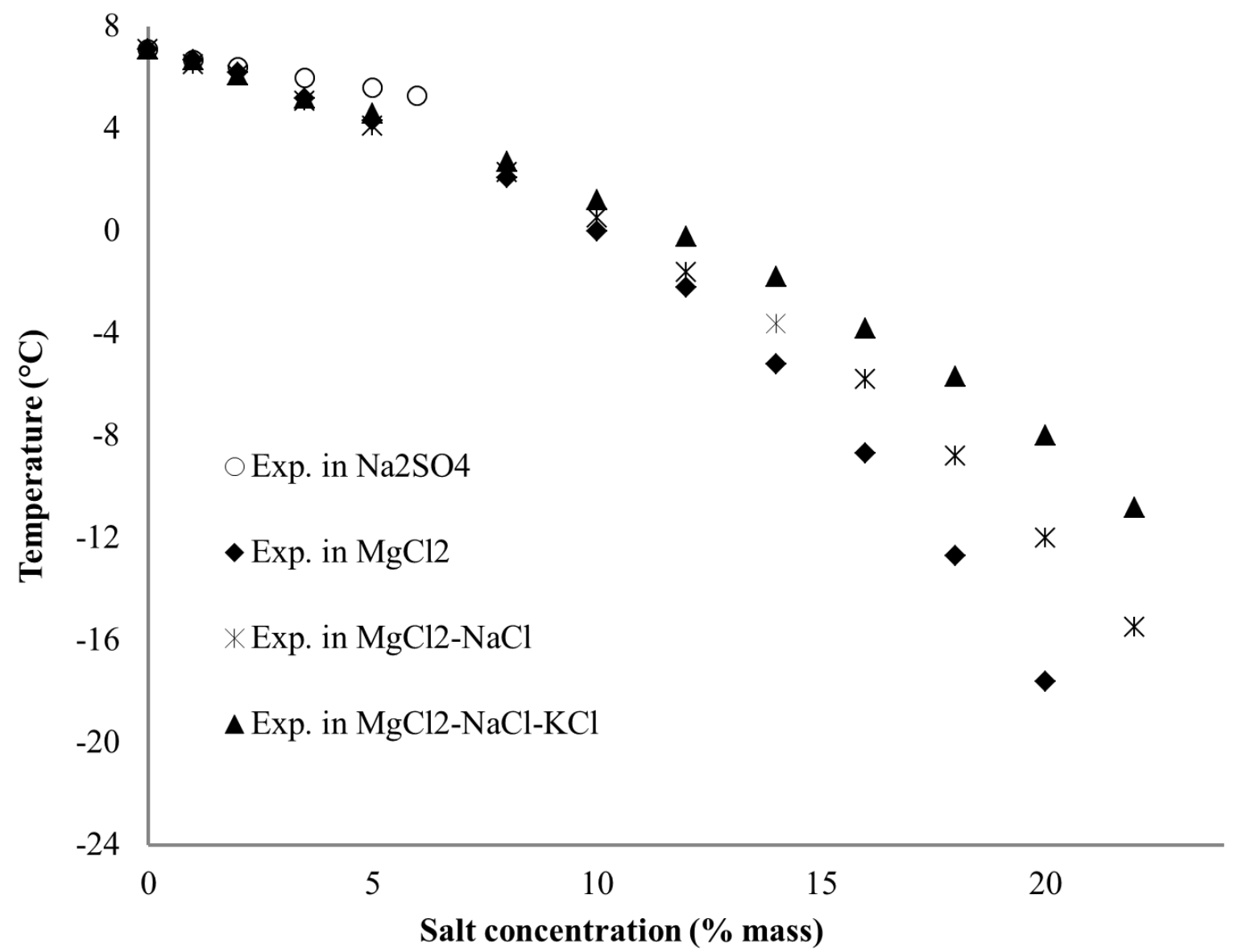

Figure 2. Experimental equilibrium temperature of $\mathrm{CPH}$ in the presence of salts (slow procedure only)

Indeed, as seen in Table A1 (in Appendix I), $\mathrm{MgCl}_{2}-\mathrm{NaCl}$ and $\mathrm{MgCl}_{2}-\mathrm{NaCl}-\mathrm{KCl}$ mixtures have approximately the same molality at the same salt concentration (in \% mass). Therefore, the variance in the dissociation point between these two brine solutions can be observe through the role of each salt when ions interact with water molecules. Table 2 illustrates that the equilibrium temperatures in the brine system of $\mathrm{MgCl}_{2}-\mathrm{NaCl}$ are lower than those in the brine system of $\mathrm{MgCl}_{2}-\mathrm{NaCl}-\mathrm{KCl}$. This means the effect of $\mathrm{NaCl}$ on phase equilibria is stronger than $\mathrm{KCl}$. In addition, $\mathrm{MgCl}_{2}$ shows the significant impact on the equilibria at concentration above $8 \%$ mass. This is because $\mathrm{MgCl}_{2}$ has a considerable influence on water activity even at lower molality at the same salt concentration (see Appendix, Table A1).

In fact, the effect of each salt on hydrate phase equilibria depends on ions charge density. Observations showed that small cations with high charge density can lead to powerful electrostatic interaction between the cations and water molecules. This weakens hydrogen bonding interaction between water molecules, inhibiting the hydrate formation. ${ }^{37,38}$ 
The ionic radius of $\mathrm{Mg}^{+2}(+2$ charge $), \mathrm{Na}^{+}(+1$ charge $)$ and $\mathrm{K}^{+}(+1$ charge $)$ are $0.78 \AA, 1.02 \AA$ and $1.38 \AA$, respectively. ${ }^{37,38}$ Hence, the charge density of $\mathrm{Mg}^{+2}$ is higher than $\mathrm{Na}^{+}$or $\mathrm{K}^{+}$. According to Sabil et al. ${ }^{37}$ and Cha et al. ${ }^{38}$, the hydrate inhibiting strength rises in the following order: $\mathrm{Mg}^{+2}$ $>\mathrm{Na}^{+}>\mathrm{K}^{+}$. This agrees well with our observation in the presence of $\mathrm{MgCl}_{2}$ (above 8\%mass), $\mathrm{MgCl}_{2}-\mathrm{NaCl}$, and $\mathrm{MgCl}_{2}-\mathrm{NaCl}-\mathrm{KCl}$.

Then, at $8 \%$ mass $\mathrm{Na}_{2} \mathrm{SO}_{4}$, when hydrate formed, co-precipitation of salt hydrates was observed at the bottom of the reactor (at temperatures less than $7^{\circ} \mathrm{C}$, see Figure 3). Indeed, according to phase diagram of $\mathrm{Na}_{2} \mathrm{SO}_{4}$ with water ${ }^{39}$, we expect $\mathrm{Na}_{2} \mathrm{SO}_{4}$ to form $\mathrm{Na}_{2} \mathrm{SO}_{4} \cdot 10 \mathrm{H}_{2} \mathrm{O}$ hydrates in the system under these conditions. Indeed, both $\mathrm{CPH}$ and $\mathrm{Na}_{2} \mathrm{SO}_{4} \cdot 10 \mathrm{H}_{2} \mathrm{O}$ hydrates dissociate concurrently when increasing temperature. When no $\mathrm{CPH}$ was observed, the temperature of system was recorded to be $5.4^{\circ} \mathrm{C}$ following the slow procedure (see Figure 4). Therefore, $5.3^{\circ} \mathrm{C}$ was recorded to be the dissociation point for $\mathrm{CPH}$ phase. However, $\mathrm{Na}_{2} \mathrm{SO}_{4}$ hydrates were still present at the bottom of the reactor. Consequently, salt concentration in aqueous phase was not $8 \%$ mass. At this moment, two samples of 1 and $5 \mathrm{ml}$ were then taken by a syringe Rhizon with a mean pore size of the porous part of $0.15 \mu \mathrm{m}$ in order to separate salts solid or any crystal from the aqueous solution (see Figure 4). Both drying oven and ionic chromatography provided an identical measured salt concentration of $6 \%$. Therefore, $5.3^{\circ} \mathrm{C}$ at $6 \%$ salt concentration is the eutectic point of the four-phase system $\left(\mathrm{Na}_{2} \mathrm{SO}_{4}+\mathrm{H}_{2} \mathrm{O}, \mathrm{Na}_{2} \mathrm{SO}_{4} \cdot 10 \mathrm{H}_{2} \mathrm{O}, \mathrm{CP}\right.$, and $\left.\mathrm{CPH}\right)$. This means that if the temperature is decreased below $5.3^{\circ} \mathrm{C}$ at $6 \%$ mass salt concentration, $\mathrm{CPH}$ and $\mathrm{Na}_{2} \mathrm{SO}_{4} \cdot 10 \mathrm{H}_{2} \mathrm{O}$ will form simultaneously. 


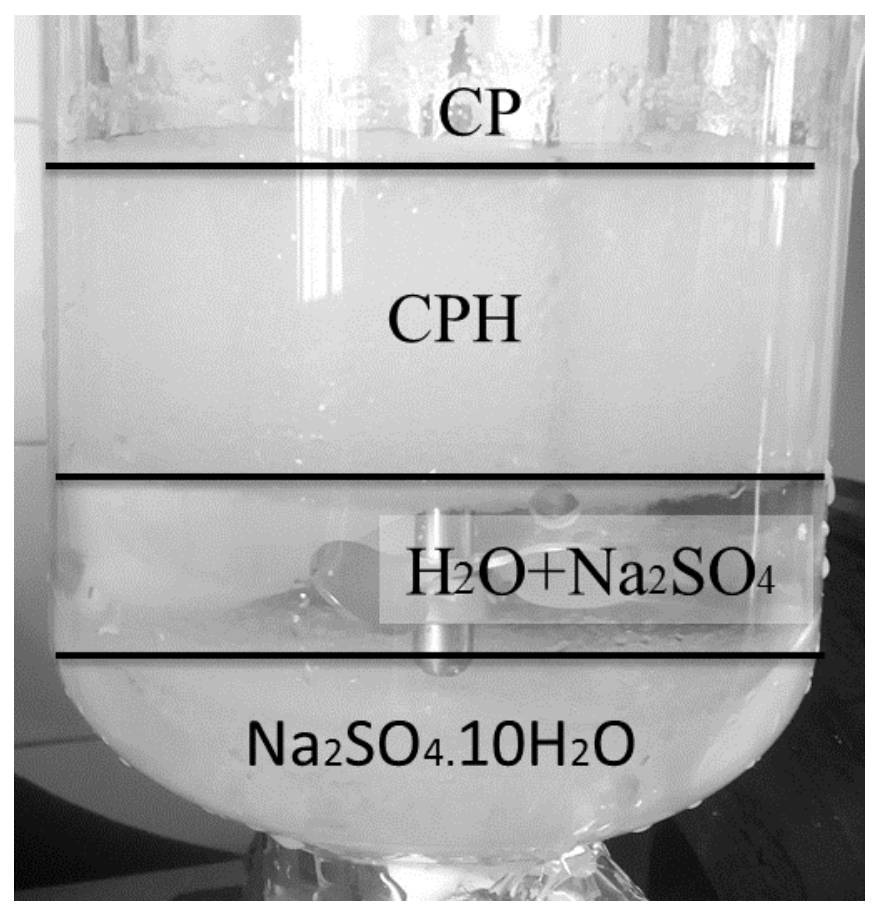

Figure 3. Photo of the experiment with $\mathrm{Na}_{2} \mathrm{SO}_{4}$ at $8 \%, 5.2^{\circ} \mathrm{C}$ following the slow procedure.

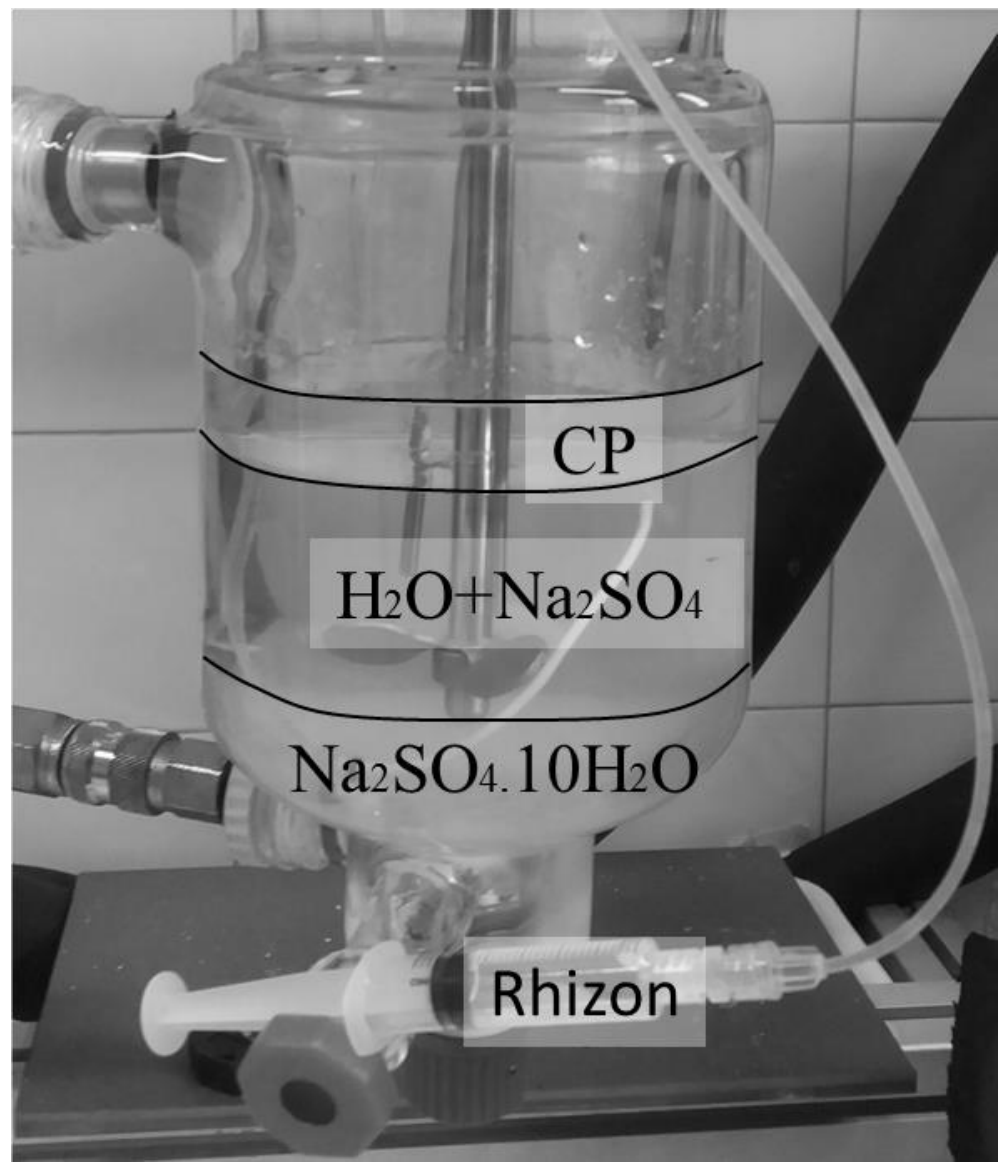

Figure 4. Photo of the experiment with $\mathrm{Na}_{2} \mathrm{SO}_{4}$ at $8 \%, 5.4^{\circ} \mathrm{C}$ following the slow procedure. 


\section{Modelling CPH thermodynamic equilibrium}

In this effort, four different approaches are utilized to model phase equilibria of $\mathrm{CPH}$ in the presence of salts. The first approach is based on the standard freezing point depression equation. ${ }^{40,41}$ The second is a new correlation by $\mathrm{Hu}$ et al. ${ }^{42,43}$, called HLS correlation. It is a derivation of the freezing point depression equation developed especially to calculate gas hydrate suppression temperatures in presence of single salts $\left(\mathrm{Hu}\right.$ et $\left.a l .{ }^{42}\right)$, or salt mixtures $\left(\mathrm{Hu}\right.$ et $\left.a l^{43}\right)$. The two others methods are based on van der Waals and Platteuw model. ${ }^{44}$ As aforementioned, these approaches are described in detail in our previous article. ${ }^{26}$

In the following, average absolute deviation $(A A D)$ between experimental and simulated results is defined as follows:

$A A D=\frac{1}{N} \sum_{i=1}^{N}\left|T_{i, p r e d}-T_{i, \exp }\right|$

where $N$ is the number of experimental data points, $T_{i, p r e d}(\mathrm{~K})$ the predicted-equilibrium temperature, and $T_{i, \exp }(\mathrm{K})$ the experimental equilibrium temperature.

\section{Standard Freezing Point Depression (SFPD) approach}

In this approach, water activity in brine with the $\mathrm{CPH}$ present is expressed as follows ${ }^{40,41}$ :

$$
\ln a_{w}=\frac{\Delta H_{f m}}{R} \frac{\left(T_{f}-T\right)}{T_{f} T}+\frac{\Delta C_{f m}}{R}\left[\frac{\left(T_{f}-T\right)}{T}-\ln \left(\frac{T_{f}}{T}\right)\right]
$$

where $T_{f}$ is the dissociation temperature in $\mathrm{K}^{45}, \Delta H_{f m}$ the molar enthalpy of dissociation in $\mathrm{J} / \mathrm{mol}^{45}, \Delta C_{f m}$ the change of molar specific heat between the sub-cooled liquid and the crystals in $\mathrm{J} / \mathrm{mol} / \mathrm{K}$, and $a_{w}$ the water activity. PHREEQC ${ }^{46}$ was employed to calculate water activity in brine using PITZER database.

$\Delta C m_{f}$ is only unknown and could not be ignored. Therefore, a correlation for $\Delta C m_{f}$ established previously ${ }^{26}$ using experimental data in the presence of $\mathrm{NaCl}$ under the form as follows:

$\Delta C_{f m}=F(T)=a \times \exp (b \times T)$

The equilibrium temperatures of $\mathrm{CPH}$ in other brine solutions $\left(\mathrm{Na}_{2} \mathrm{SO}_{4}, \mathrm{MgCl}_{2}, \mathrm{MgCl}_{2}-\mathrm{NaCl}\right.$, or $\mathrm{MgCl}_{2}-\mathrm{NaCl}-\mathrm{KCl}$ ) are then calculated by using both equations (2) and the (3). 


\section{Hu-Lee-Sum (HLS) correlation}

Hu et al. ${ }^{42,43}$ observed that $\frac{n R}{\Delta H_{\text {diss }}}$ remains constant, while $\frac{\Delta T}{T_{0} T}$ only depends on the effective mole fraction. Therefore, they developed a new correlation for the suppression temperature $\left(\Delta \mathrm{T}=\mathrm{T}_{\mathrm{o}}-\right.$ $\mathrm{T})$ based on equation (2) as follows: ${ }^{42,43,47}$

$\frac{\Delta \mathrm{T}}{T_{0} T}=-\frac{\mathrm{nR}}{\Delta \mathrm{H}_{\text {diss }}} \ln a_{w}=C_{1} X+C_{2} X^{2}+C_{3} X^{3}$

where $T_{o}$ and $T$ are the hydrate equilibrium temperatures in pure water and brine solution, respectively. $\Delta H_{\text {diss }}$ is the hydrate dissociation enthalpy, $n$ the hydration number, and $a_{w}$ the water activity. $C_{1}, C_{2}$, and $C_{3}$ are fitted coefficients, $X$ the effective mole fraction. $X$ can be expressed as follows ${ }^{43}$ :

$\mathrm{X}=\sum_{j=\text { salts }} \sum_{i=\text { ions }}\left|z_{j, i}\right| x_{j, i}$

where $i$ and $j$ represent the ion and salt, respectively. $z$ is the ion charge number, $x$ the mole fraction. In the end, the hydrate formation temperature is:

$T=T_{0}\left[1+\left(\frac{\Delta \mathrm{T}}{T_{0} T}\right) T_{0}\right]^{-1}$

Equation (4) was originally developed for structure I hydrates, but has been derived for salt mixtures and structure II hydrates lately. ${ }^{43}$ To account for SII hydrates, the authors suggested a new parameter $\alpha$ :

$\alpha=\frac{\left(\frac{\Delta \mathrm{T}}{T_{0} T}\right)_{S I I}}{\left(\frac{\Delta \mathrm{T}}{T_{0} T}\right)_{S I}}$

So that:

$T=T_{0}\left[1+\alpha\left(\frac{\Delta \mathrm{T}}{T_{0} T}\right)_{I} T_{0}\right]^{-1}$

By this mean, SII hydrate suppression temperature is correlated to SI suppression temperature. In our work, the studied system is different since no gas molecules are considered. Instead, cyclopentane is the guest molecule, and the pressure dependency of $\mathrm{CPH}$ is negligible. Therefore, we first checked $\mathrm{Hu}$ et al. assumption in water+CP+salt systems considering the same salts $\left\{\mathrm{NaCl}, \mathrm{KCl}, \mathrm{CaCl}_{2}, \mathrm{MgCl}_{2}\right\}$. Figure 5 shows that $\frac{\Delta \mathrm{T}}{T_{0} T}$ is indeed strongly correlated to the effective mole fraction (see also equation 4), although there is a slight deviation for $\mathrm{MgCl}_{2}$ system at high concentrations $(X>0.15)$.

Since the parameters furnished by $\mathrm{Hu}$ et $a l .^{42}$ have not led to satisfactory simulation for $\mathrm{CPH}$ formation temperature (see Appendix II), data from Figure 5 have been used to optimize $C_{1}, C_{2}$, 
and $C_{3}$ coefficients. Note that, on Figure 5, dissociation points of $\mathrm{CPH}$ in the presence of $\mathrm{NaCl}$, $\mathrm{KCl}$, and $\mathrm{CaCl}_{2}$ come from Ho-Van et al. ${ }^{26}$ and results involving $\mathrm{MgCl}_{2}$ come from the present work. Figure 5 shows the $\mathrm{CPH}$ depression temperature versus the effective mole fraction of $\mathrm{NaCl}$, $\mathrm{KCl}, \mathrm{CaCl}_{2}$, and $\mathrm{MgCl}_{2}$. Based on Figure 5, and $\mathrm{Hu}$ et al., $\frac{\Delta \mathrm{T}}{\mathrm{T}_{0} \mathrm{~T}}$ can be expressed as a fitted function of $X$ as follow (regression coefficient $R=0.990$ ):

$\frac{\Delta \mathrm{T}}{T_{0} T}=0.000956623 \mathrm{X}+0.00059779 X^{2}+0.01897593 X^{3}$

Hence, $C_{1}, C_{2}$, and $C_{3}$ for $\mathrm{CPH}$ are now determined to be $0.000956623,0.00059779$, and 0.01897593 , respectively.

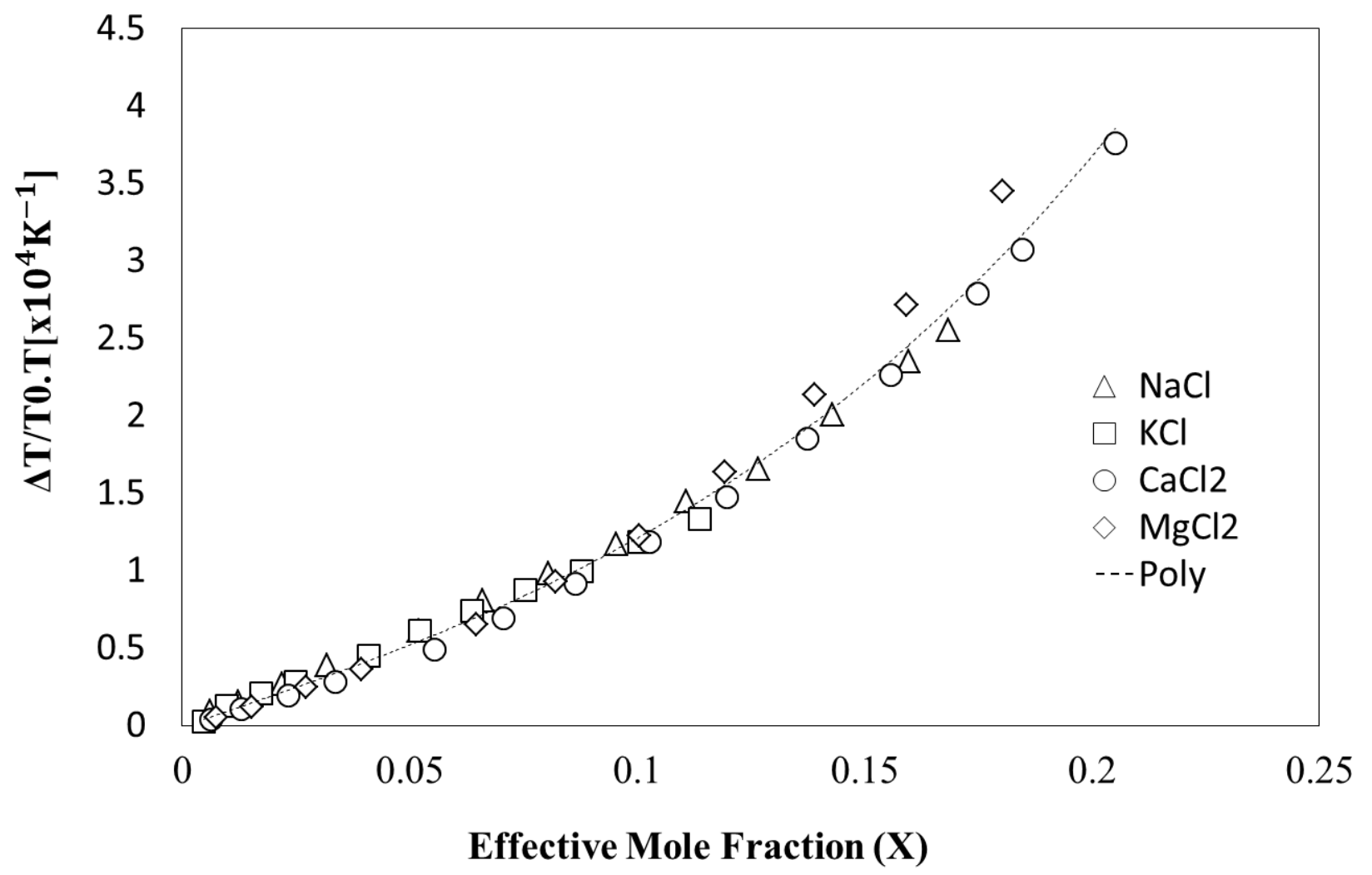

Figure 5. The $\mathrm{CPH}$ hydrate depression temperature versus the effective mole fraction of $\mathrm{NaCl}$, $\mathrm{KCl}, \mathrm{CaCl}_{2}$, and $\mathrm{MgCl}_{2}$. 


\section{Kihara Approach}

van der Waals and Platteeuw model ${ }^{44}$ is a standard approach in clathrate science ${ }^{1}$. Its use for CPH crystallization from brine has been explained by Ho-Van et al. ${ }^{2}$. Therefore, it will not be detailed in this section. However, for the sake of understanding, here is some basic information.

Equilibrium is calculated by searching uniform chemical potentials of water in both liquid and hydrate phase. A reference state $(\beta)$ is used: the empty clathrate. Hence, it can be expressed as follow:

$\Delta \mu_{w}^{\beta-H}=\Delta \mu_{w}^{\beta-L}$

$\Delta \mu_{w}^{\beta-L}$, the difference between chemical activity of water in $\beta$ state and liquid phase can be expressed from the Gibbs-Duhem equation ${ }^{48}$, whilst $\Delta \mu_{w}^{\beta-H}$, the difference between $\beta$ state and hydrate phase can be calculated via van der Waals and Platteeuw model as follows:

$\Delta \mu_{w}^{\beta-H}=-R T \sum_{i} v_{i} \ln \left(1-\sum_{j} \theta_{j}^{i}\right)$

where $R$ is the universal gas constant, $T$ the absolute temperature, $v_{i}$ the number of type $i$ cavities per water molecule in the hydrate (just 8/136 for CPH since cyclopentane only occupies large

cavities of SII), and $\theta_{j}^{i}$ the occupancy factor $\left(\theta_{j}^{i} \in[0,1]\right)$ of the cavities of type $i$ by the guest molecule $j$ (the guest molecule here is $\mathrm{CP}$ ). Occupancy factor $\theta_{j}^{i}$ can be obtained from integration of Kihara potential (Parrish et al. ${ }^{49}$ ), and fugacity of guest molecules. It will not be developed hereafter. However, the reader should now be aware that calculation of $\Delta \mu_{w}^{\beta-H}$ is possible under the condition that Kihara parameters (maximum attractive potential $\varepsilon$, distance between the cores at zero potential energy $\sigma$, and the hard-core radius $a$ ) are available. In our previous work, optimization of these parameters for cyclopentane has been performed for $\varepsilon$ and $a$ (the hard core radius is supposed to be known). Results are presented in Figure 8.

In this approach, activity of water is needed for the chemical potential of water in liquid phase, as well as specific thermodynamic properties. Like the first approach, PHREEQC has been used for water activity. The others parameters have been chosen, and taken from literature, based on previous work and observation (Herri et al. ${ }^{48}$ and Ho-Van et al. ${ }^{26}$ ). 


\section{Activity-Based Occupancy Correlation (ABOC) approach}

The fourth approach is similar to the latest. However, instead of using Kihara parameters, ergo an interaction potential, a more simple approach has been used. Instead of considering a Langmuir type method for the occupancy of cavities, an elementary correlation between the occupancy factor and water activity, $\theta=F\left(a_{w}\right)$, can be used. ${ }^{26}$ By this mean, the knowledge of water activity (with PHREEQC, or any activity coefficient method, for instance) is enough to estimate $\theta$. The correlation is expressed as follow:

$\theta\left(a_{w}\right)=m \times\left(a_{w}^{2}\right)+n \times\left(a_{w}\right)+p$

where $m, n$ and $p$ are the empirical constants reported by Ho-Van et al. ${ }^{26}$ : -0.0004772 , 0.0004731 , and 0.9998800 respectively. Note that these constants have been obtained from CPH equilibrium points in water $+\mathrm{NaCl}$ mixtures only.

\section{Modelling results}

\section{SFPD approach}

Figure 6 illustrates the experimental and predicted equilibrium temperatures according to the SFPD approach. Absolute average deviations are: $0.1^{\circ} \mathrm{C}$ in $\mathrm{Na}_{2} \mathrm{SO}_{4} ; 0.3^{\circ} \mathrm{C}$ in $\mathrm{MgCl}_{2}-\mathrm{NaCl}-\mathrm{KCl}$; $0.4^{\circ} \mathrm{C}$ in $\mathrm{MgCl}_{2}-\mathrm{NaCl}$; and $0.5^{\circ} \mathrm{C}$ in $\mathrm{MgCl}_{2}$. Results indicate that dissociation temperatures are relatively well reproduced using the $\Delta C m_{f}(T)$ correlation for $\mathrm{CPH}$.

Unfortunately, there is a significant gap between the modelling and experimental data in presence of $\mathrm{MgCl}_{2}$ ( $\geq 18 \%$ mass) and $\mathrm{MgCl}_{2}-\mathrm{NaCl}$ mixture ( $\geq 20 \%$ mass). This might be due to water activity calculations. However, since our fourth approach (ABOC) provides better results using the same estimation tool (PHREEQC), deviations seem to be due to the method itself and its simplified hypothesis (considering $\mathrm{CPH}$ as a pure water crystal with its specific thermodynamic properties). 


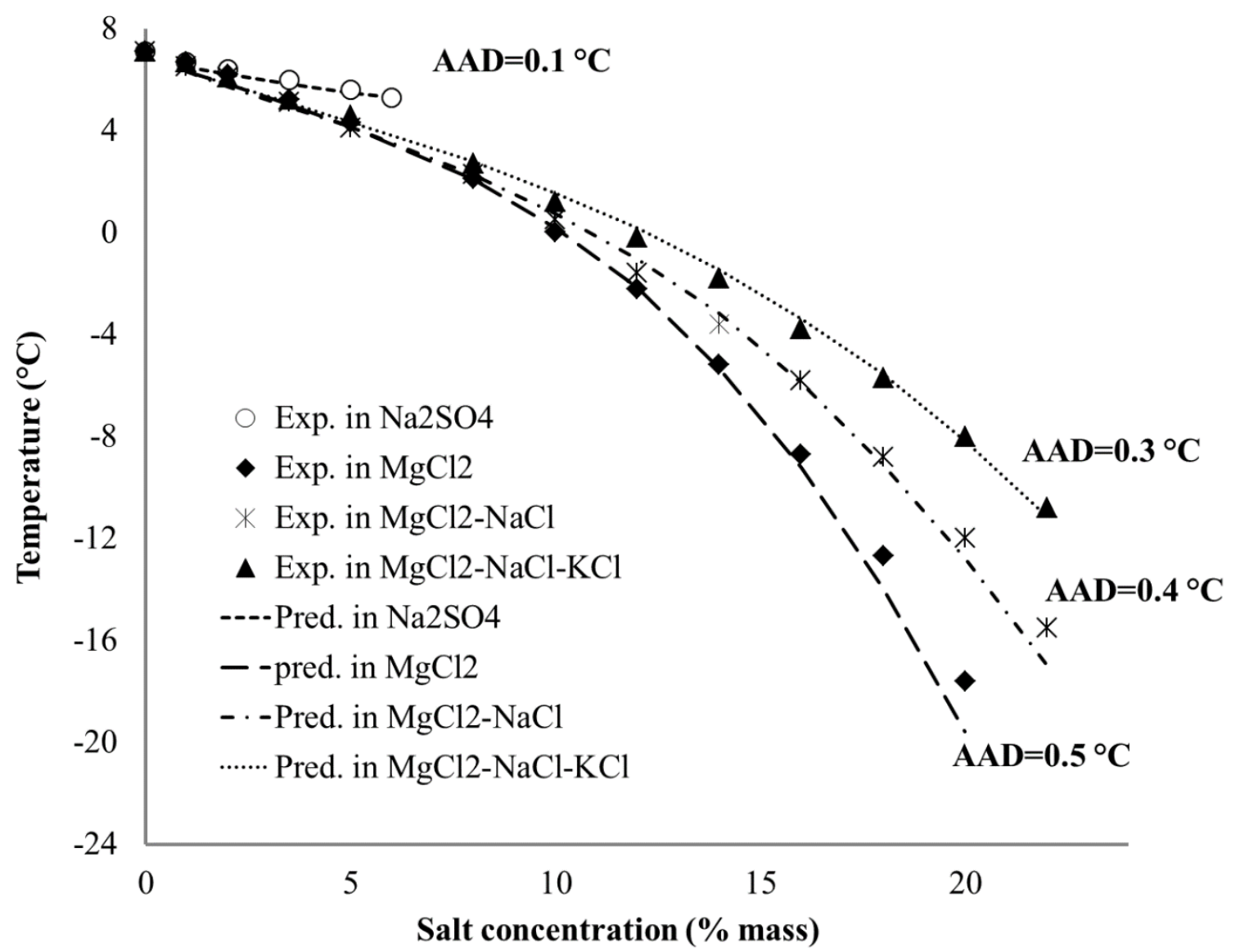

Figure 6. Experimental and predicted dissociation temperature of $\mathrm{CPH}$ in the presence of salts according to the SFPD approach

\section{HLS correlation}

The $\mathrm{CPH}$ equilibrium temperatures in brine solutions of $\mathrm{MgCl}_{2}-\mathrm{NaCl}, \mathrm{MgCl}_{2}-\mathrm{NaCl}-\mathrm{KCl}$, or $\mathrm{Na}_{2} \mathrm{SO}_{4}$ have predicted using equation (6) using the three coefficients obtained earlier (equation 9). Simulated results are presented in Figure 7. They are in relatively good agreement with the measured data. Average absolute deviations are: $0.3^{\circ} \mathrm{C}$ for $\mathrm{Na}_{2} \mathrm{SO}_{4}, 0.2^{\circ} \mathrm{C}$ for $\mathrm{MgCl}_{2}-\mathrm{NaCl}-\mathrm{KCl}$, $0.4^{\circ} \mathrm{C}$ for $\mathrm{MgCl}_{2}-\mathrm{NaCl}$, and $0.7^{\circ} \mathrm{C}$ for $\mathrm{MgCl}_{2}$.

HLS correlation is however less comfortable with $\mathrm{MgCl}_{2} \cdot{ }^{42}$ This is not surprising when looking at

Figure 5. Indeed, there is a behavior deviation from equation (9) (higher $\frac{\Delta T}{T_{0} T}$ than correlation curve for $\mathrm{X}>0.15)$. 


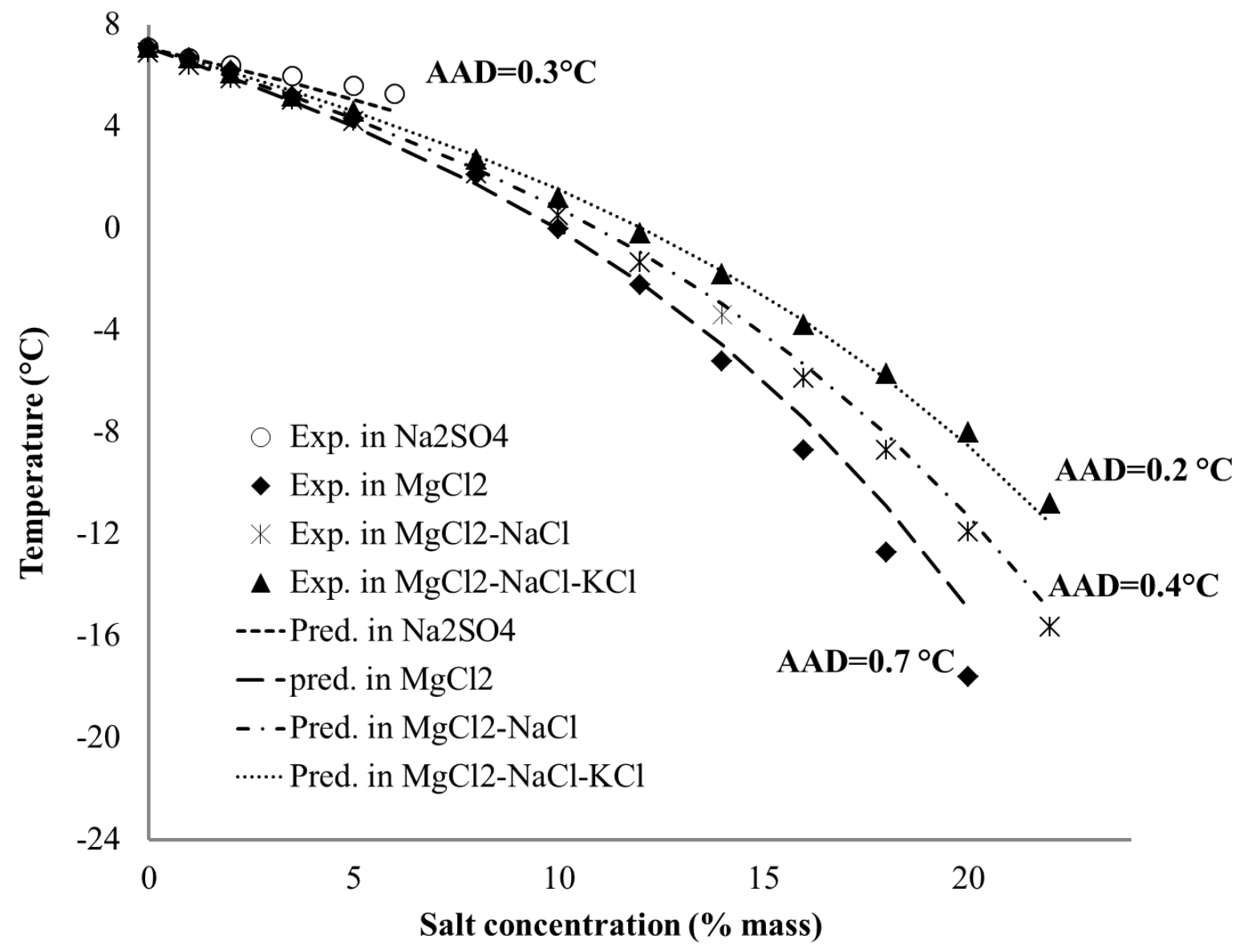

Figure 7. Experimental and predicted dissociation temperature of $\mathrm{CPH}$ in the presence of salts according to HLS approach

\section{Kihara approach}

Figure 8 reveals the experimental and predicted hydrate equilibrium temperatures of Kiharabased method. In this case, the simulated results agree reasonably well with the experimental data. Average absolute deviations are less than $0.2^{\circ} \mathrm{C}$ in the presence of $\mathrm{Na}_{2} \mathrm{SO}_{4}, \mathrm{MgCl}_{2}-\mathrm{NaCl}$, or $\mathrm{MgCl}_{2}-\mathrm{NaCl}-\mathrm{KCl}$, and regrettably about $0.5^{\circ} \mathrm{C}$ in presence of $\mathrm{MgCl}_{2}$. 


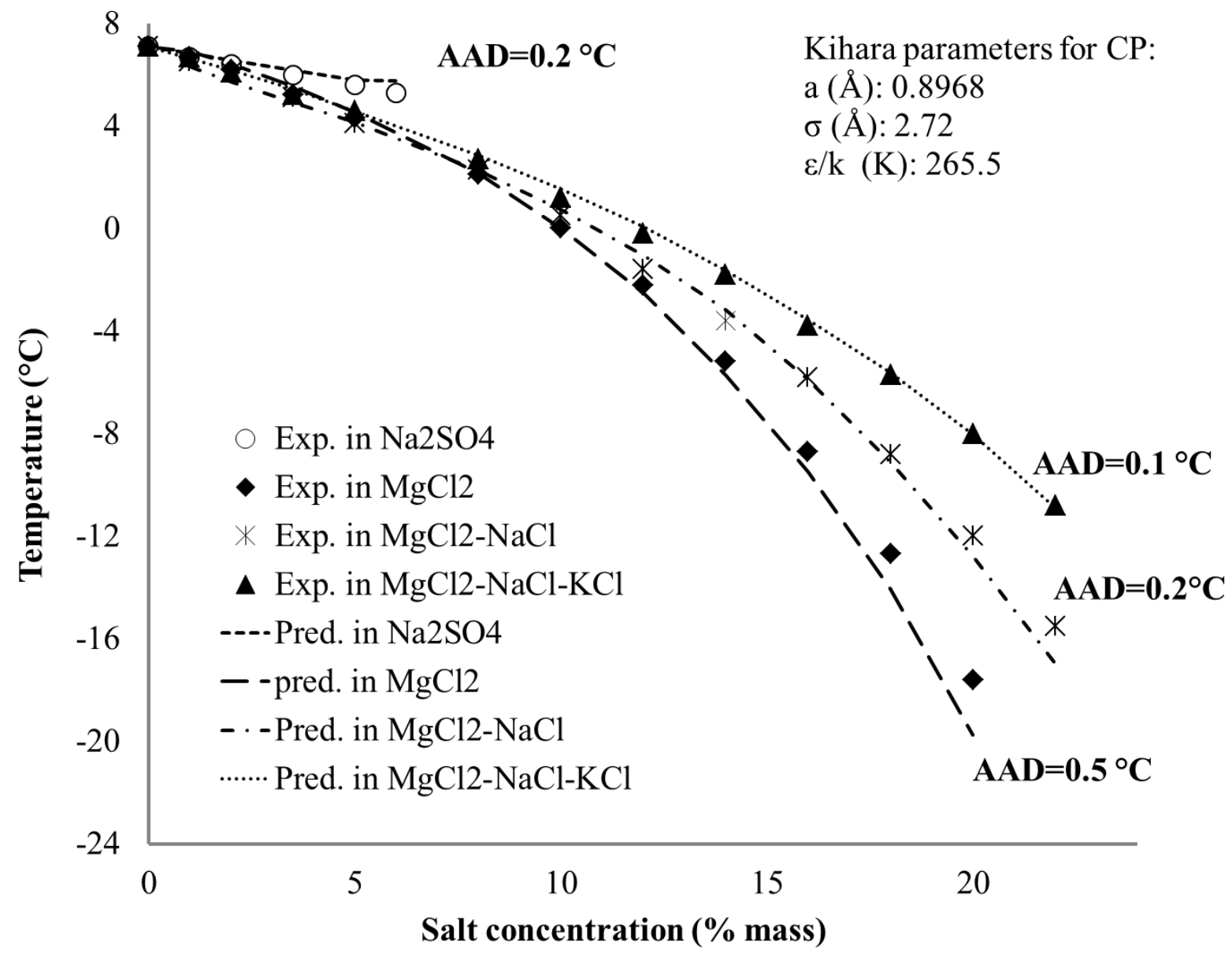

Figure 8. Experimental and predicted dissociation temperature of $\mathrm{CPH}$ in the presence of salts, and Kihara parameters for $\mathrm{CP}$ obtained by using the experimental data in $\mathrm{NaCl}$

\section{Activity-Based Occupancy Correlation (ABOC)}

The simulated results of $\mathrm{CPH}$ phase equilibrium with $\mathrm{ABOC}$ method are presented in Figure 9. Predicted results agree well with the experimental data. Importantly, the average absolute deviation is about $0.1^{\circ} \mathrm{C}$ for either $\mathrm{Na}_{2} \mathrm{SO}_{4}$ or $\mathrm{MgCl}_{2}-\mathrm{NaCl}$ or $\mathrm{MgCl}_{2}-\mathrm{NaCl}-\mathrm{KCl}$ and about $0.2^{\circ} \mathrm{C}$ for $\mathrm{MgCl}_{2}$. This shows that the $\mathrm{ABOC}$ approach reproduce successfully the experimental dissociation temperatures for $\mathrm{CPH}$ in all cases. Note that it was already the recommended approach to use in the previous study ${ }^{26}$ and here its application is extended. These superb new results solidify that activity-based occupancy correlation $(\mathrm{ABOC})$ is the best method to use so far. 


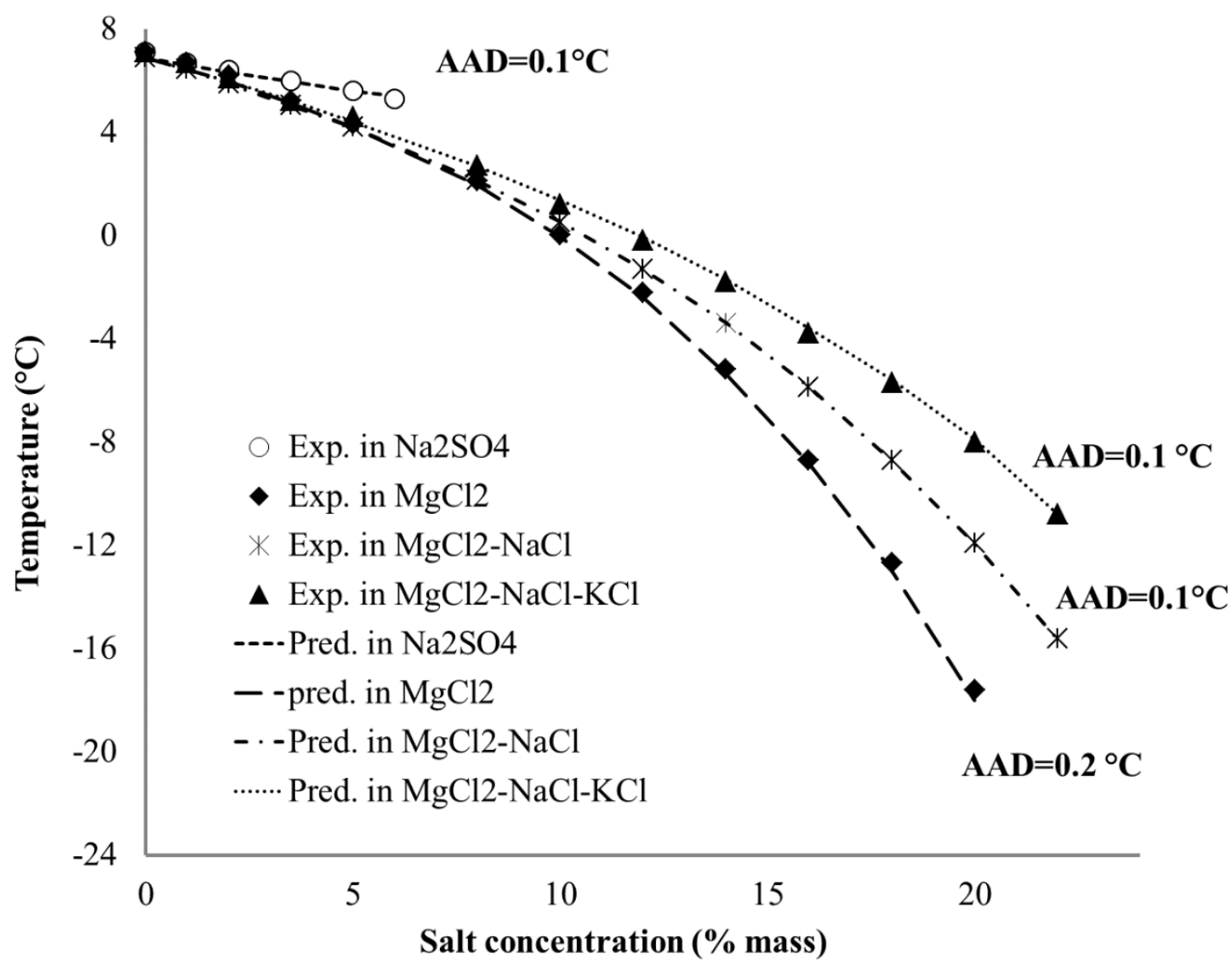

Figure 9. Experimental and predicted dissociation temperature of $\mathrm{CPH}$ in the presence of salts according to the $\mathrm{ABOC}$ approach.

\section{Discussion on the models}

The average deviation between the present simulation and the experimental data and from HoVan et al. ${ }^{26}$ are listed in Table 4. Note that HLS deviations for the former systems $(\mathrm{NaCl}, \mathrm{KCl}$, or $\mathrm{MgCl}_{2}$ ) have been calculated and are presented in Appendix III. As highlighted in this table, all three approaches can reproduce acceptably the $\mathrm{CPH}$ phase equilibrium temperature. The average deviations are reported to be less than, or equal to $0.7^{\circ} \mathrm{C}$ in all brine systems.

In addition, the Kihara (except for $\mathrm{MgCl}_{2}$ ) and $\mathrm{ABOC}$ methods predict satisfactorily $\mathrm{CPH}$ formation temperature. As stated by Ho-Van et al. ${ }^{26}$, the weakness of the Kihara method is that it requires Kihara potential integration. This can lead to different final values depending on the calculation code, and it is also influenced by the use of the Antoine equation for $\mathrm{CP}$ vapor pressure. Consequently, the ABOC approach is the strongest model to achieve rapid and consistent $\mathrm{CPH}$ equilibrium temperature from different brine systems. 
Finally, HLS correlation, while being also useful and very simple to use, seems to be less versatile in terms of systems (especially $\mathrm{MgCl}_{2}$ ) since it is based on effective mole fraction. However, this correlation seems promising because of the excellent results the authors obtained for gas hydrates. Maybe new developments of this correlation for heavier non-gaseous guest molecules, such as cyclopentane, are necessary to provide a more accomplished tool.

Table 4. Average deviation (in ${ }^{\circ} \mathrm{C}$ or $\mathrm{K}$ ) of different approaches for predicting $\mathrm{CPH}$ equilibrium temperature.

\begin{tabular}{ccccccccc}
\hline Approach & $\mathrm{Na}_{2} \mathrm{SO}_{4}$ & $\mathrm{MgCl}_{2}$ & $\mathrm{MgCl}_{2}-\mathrm{NaCl}$ & $\mathrm{MgCl}_{2^{-}}$ & $\mathrm{NaCl}^{26}$ & $\mathrm{KCl}^{26}$ & $\mathrm{NaCl}^{-}$ & $\mathrm{CaCl}_{2}{ }^{26}$ \\
& & & & & & & \\
& & & & & & $\mathrm{KCl}^{26}$ \\
SFPD & 0.1 & 0.5 & 0.4 & 0.3 & 0.3 & 0.3 & 0.2 & 0.4 \\
HLS & 0.3 & 0.7 & 0.4 & 0.2 & 0.5 & 0.3 & 0.3 & 0.5 \\
Kihara & 0.2 & 0.5 & 0.2 & 0.1 & 0.2 & 0.1 & 0.1 & 0.2 \\
ABOC & 0.1 & 0.2 & 0.1 & 0.1 & 0.1 & 0.1 & 0.1 & 0.2 \\
\hline
\end{tabular}

\section{Conclusion}

The dissociation temperature of $\mathrm{CPH}$ in four different brine systems $\mathrm{Na}_{2} \mathrm{SO}_{4}, \mathrm{MgCl}_{2}, \mathrm{MgCl}_{2}$ $\mathrm{NaCl}$, or $\mathrm{MgCl}_{2}-\mathrm{NaCl}-\mathrm{KCl}$ were determined experimentally following two different procedures: quick and slow. First essential approximations on $\mathrm{CPH}$ phase equilibrium data were obtained by the quick procedure, then more trustworthy and consistent measurements were provided by the slow dissociation. A temperature gap between the dissociation temperatures following two procedures was observed. Because the quick procedure is likely to misjudge the correct value, its recorded measurements were hence slightly higher than the right dissociation point in all brine systems tested.

Results also point to that the $\mathrm{CPH}$ dissociation temperature decreased considerably with increasing in brine concentration due to two well-known phenomena: clustering and salting-out. In addition, differing brine systems show dissimilar effects on the dissociation temperature: $\mathrm{Na}_{2} \mathrm{SO}_{4}$ exhibits the smallest effect at concentration from $1 \%$ to $5 \%$ mass whilst $\mathrm{MgCl}_{2}$ displays 
the great impact on the equilibria at concentration above $8 \%$. Furthermore, the equilibrium temperatures in the brine system of $\mathrm{MgCl}_{2}-\mathrm{NaCl}$ are reported to be lower than those in the brine system of $\mathrm{MgCl}_{2}-\mathrm{NaCl}-\mathrm{KCl}$ at any salt concentration. This means the effect of $\mathrm{NaCl}$ on phase equilibria is stronger than $\mathrm{KCl}$. In addition, the eutectic point of the four-phase system $\mathrm{Na}_{2} \mathrm{SO}_{4}+$ $\mathrm{H}_{2} \mathrm{O}, \mathrm{Na}_{2} \mathrm{SO}_{4} \cdot 10 \mathrm{H}_{2} \mathrm{O}, \mathrm{CP}$, and $\mathrm{CPH}$ was also recorded at $6 \%$ mass $\mathrm{Na}_{2} \mathrm{SO}_{4}$ at $5.3^{\circ} \mathrm{C}$.

Lastly, four thermodynamic approaches were employed, including the novel HLS correlation

from $\mathrm{Hu}$ et al. ${ }^{42,43}$ to predict $\mathrm{CPH}$ dissociation temperatures. Simulated results show that all four approaches reproduced adequately the $\mathrm{CPH}$ dissociation temperature with an average deviation less than $0.7{ }^{\circ} \mathrm{C}$. However, the activity-based occupancy correlation (ABOC) method is overall better. This is the recommended method to achieve rapid and reliable equilibrium temperatures of $\mathrm{CPH}$ in different brine systems, with a deviation less than $0.2^{\circ} \mathrm{C}$.

\section{Notation}

a water activity [-] or Kihara parameter, spherical nucleus radius [m], coefficients [-] for the correlation of the change of molar specific heat

$b \quad$ coefficient linear temperature dependency of the heat capacity $\left[\mathrm{J} \mathrm{mol} \mathrm{K}^{-2}\right]$, and coefficients $[-]$ for the correlation of the change of molar specific heat

C fitted coefficient in the HLS approach

$\mathrm{H} \quad$ molar enthalpy $\left[\mathrm{J} \mathrm{mol}^{-1}\right]$

m coefficient of the correlation of the cage occupancy

$\mathrm{N}$ number of points of a given set of data

n mole number, coefficient of the correlation of the cage occupancy

$\mathrm{P} \quad$ pressure $[\mathrm{Pa}]$

$\mathrm{p} \quad$ coefficient of the correlation of the cage occupancy

$\mathrm{R} \quad$ universal gas constant $\left[8.314472 \mathrm{~m}^{2} \mathrm{~kg} \mathrm{~s}^{-2} \mathrm{~K}^{-1} \mathrm{~mol}^{-1}\right]$,

$\mathrm{T}$ temperature $[\mathrm{K}]$

$\mathrm{x} \quad$ mole fraction

$\mathrm{X}$ effective mole fraction

$\mathrm{Z} \quad$ ion charge number

Greek letters

$\varepsilon \quad$ Kihara parameter, maximum attraction potential [-]

$\mu \quad$ Chemical potential [J mol-1] 
$v \quad$ number of cavities per molecules of water [-]

$\theta \quad$ occupation rate of cavity/gas

$\sigma \quad$ Kihara parameter, distance between the molecules and the cavity wall, at null potential [m]

$\alpha \quad$ Hu-Lee-Sum parameter accounts for the hydrate structure difference [-]

$\beta \quad$ Hu-Lee-Sum parameter represents the hydrate suppression temperature [-]

Superscripts

$\mathrm{H}$ hydrate phase

L liquid phase

$\beta \quad$ hypothetical reference phase for the hydrate phase corresponding to empty lattice

\section{Acknowledgements}

The authors would like also to thank Christopher Yukna very much for his advice on English and proofreading. 


\section{APPENDIX I. Molality, effective mole fraction, and water activity}

Table A1. Molality, effective mole fraction (X), and water activity (calculated by using PHREEQC $^{46}$ at the CPH dissociation point) of four brine solutions

\begin{tabular}{|c|c|c|c|c|c|c|c|c|c|c|c|c|}
\hline \multirow{2}{*}{$\begin{array}{c}\text { Salinity } \\
\text { in } \% \\
\text { mass }\end{array}$} & \multicolumn{3}{|c|}{$\mathrm{Na}_{2} \mathrm{SO}_{4}$} & \multicolumn{3}{|c|}{$\mathrm{MgCl}_{2}$} & \multicolumn{3}{|c|}{$\mathrm{MgCl}_{2}-\mathrm{NaCl}$} & \multicolumn{3}{|c|}{$\mathrm{MgCl}_{2}-\mathrm{NaCl}-\mathrm{KCl}$} \\
\hline & Molality & $\mathrm{X}$ & $\begin{array}{l}\text { Water } \\
\text { activity }\end{array}$ & Molality & $\mathrm{X}$ & $\begin{array}{l}\text { Water } \\
\text { activity }\end{array}$ & Molality & $\mathrm{X}$ & $\begin{array}{l}\text { Water } \\
\text { activity }\end{array}$ & Molality & $\mathrm{X}$ & $\begin{array}{l}\text { Water } \\
\text { activity }\end{array}$ \\
\hline 0 & 0.000 & 0.000 & 1.000 & 0.000 & 0.000 & 1.000 & 0.000 & 0.000 & 1.000 & 0.000 & 0.000 & 1.000 \\
\hline 1 & 0.071 & 0.005 & 0.997 & 0.106 & 0.008 & 0.995 & 0.140 & 0.007 & 0.995 & 0.138 & 0.006 & 0.995 \\
\hline 2 & 0.144 & 0.010 & 0.994 & 0.214 & 0.015 & 0.990 & 0.282 & 0.014 & 0.989 & 0.279 & 0.013 & 0.990 \\
\hline 3.5 & 0.255 & 0.018 & 0.990 & 0.381 & 0.027 & 0.981 & 0.501 & 0.025 & 0.980 & 0.496 & 0.022 & 0.982 \\
\hline 5 & 0.371 & 0.027 & 0.986 & 0.553 & 0.039 & 0.971 & 0.727 & 0.036 & 0.971 & 0.720 & 0.032 & 0.973 \\
\hline 6 & 0.449 & 0.032 & 0.984 & & - & - & - & - & - & - & - & - \\
\hline 8 & - & & - & 0.913 & 0.065 & 0.947 & 1.201 & 0.058 & 0.949 & 1.190 & 0.053 & 0.955 \\
\hline 10 & - & & - & 1.167 & 0.082 & 0.926 & 1.535 & 0.074 & 0.932 & 1.520 & 0.067 & 0.941 \\
\hline 12 & - & & - & 1.432 & 0.101 & 0.902 & 1.884 & 0.090 & 0.913 & 1.865 & 0.082 & 0.926 \\
\hline 14 & - & & - & 1.710 & 0.119 & 0.872 & 2.249 & 0.107 & 0.892 & 2.227 & 0.097 & 0.909 \\
\hline 16 & - & & - & 2.001 & 0.139 & 0.838 & 2.631 & 0.125 & 0.867 & 2.606 & 0.113 & 0.890 \\
\hline 18 & - & & - & 2.306 & 0.159 & 0.798 & 3.032 & 0.143 & 0.839 & 3.003 & 0.129 & 0.870 \\
\hline 20 & - & & - & 2.626 & 0.181 & 0.751 & 3.453 & 0.161 & 0.808 & 3.420 & 0.146 & 0.847 \\
\hline 22 & - & & - & - & - & - & 3.896 & 0.181 & 0.773 & 3.858 & 0.163 & 0.822 \\
\hline
\end{tabular}

\section{APPENDIX II. Use of HLS correlation with Hu et al. coefficients}

First thing we did when utilizing HLS correlation was to use $\mathrm{Hu}$ et al. parameter. ${ }^{42}$ Since cyclopentane is the guest, and not methane or other light hydrocarbon, and since $\mathrm{CPH}$ form structure II, the second work from $\mathrm{Hu}$ et $a l .{ }^{43}$ was considered. In this effort, SII hydrate suppression temperature is written:

$\left(\frac{\Delta \mathrm{T}}{T_{0} T}\right)_{I I}=\alpha\left(\frac{\Delta \mathrm{T}}{T_{0} T}\right)_{I}=\alpha\left(C_{1} X+C_{2} X^{2}+C_{3} X^{3}\right)$

And the hydrate dissociation temperature can be calculated from:

$T=T_{0}\left[1+\alpha\left(\frac{\Delta \mathrm{T}}{T_{0} T}\right)_{I} T_{0}\right]^{-1}$ 
Coefficient $\alpha$ can be estimated from the ratio $\beta_{2} / \beta_{1}$ :

$\frac{\left(\frac{\Delta \mathrm{T}}{T_{0} T}\right)_{I I}}{\left(\frac{\Delta \mathrm{T}}{T_{0} T}\right)_{I}}=\frac{R \ln \left(a_{w}\right)\left(\frac{n}{\Delta H_{\text {diss }}}\right)_{I I}}{R \ln \left(a_{w}\right)\left(\frac{n}{\Delta H_{\text {diss }}}\right)_{I}}=\frac{\beta_{2}}{\beta_{1}}=\alpha$

This ration accounts for the hydrate structure difference. Two methods are suggested by $\mathrm{Hu}$ et $a l^{43}$ to calculate $\alpha$ : optimization from experimental data, or evaluation of hydrate dissociation heat and hydration number for direct calculation. We first tried to optimize $\alpha$ as a constant using equilibrium data in $\{$ water $+\mathrm{NaCl}\}$ solutions, using $C_{1}, C_{2}$ and $C_{3}$ parameters from $\mathrm{Hu}$ et al ${ }^{42}$ In our opinion, results were not satisfactory ( $\mathrm{AAD}=0.8$, see Table $\mathrm{A} 2$ ).

Then, we optimized $\alpha$ for each equilibrium point, trying to find a correlation under the form $\alpha=\alpha(X)$. Table $\mathrm{A} 2$ presents the results for water $+\mathrm{NaCl}$ system. Obviously, since $\alpha$ was adjusted for each point, the new predictions fit perfectly the experimental data (AAD $=0$ ). However, our intention was to find an appropriate correlation for $\alpha$, under the form $\alpha=\alpha(X)$. Unfortunately, the correlation $\alpha(X)$ remains under a complicated form, as shown in Figure A2. This is why we chose to optimize $C_{1}, C_{2}, C_{3}$ coefficients in our work. 
Table A2. Optimization with $\alpha$ constant and not constant

\begin{tabular}{|c|c|c|c|c|c|c|c|c|}
\hline \multicolumn{3}{|c|}{ Experimental } & \multicolumn{6}{|c|}{ Optimization } \\
\hline & & & \multicolumn{3}{|c|}{$\alpha$ constant } & \multicolumn{3}{|c|}{$\alpha$ not constant } \\
\hline $\begin{array}{l}\text { Salinity, \% } \\
\text { mass }\end{array}$ & $X$ & $\begin{array}{c}\mathrm{T}_{\text {exp }}, \\
{ }^{\circ} \mathrm{C}\end{array}$ & $\alpha$ & $\frac{\Delta \mathrm{T}}{T_{0} T}$ & $\begin{array}{c}\mathrm{T}_{\text {pred }}, \\
{ }^{\circ} \mathrm{C}\end{array}$ & $\alpha$ & $\frac{\Delta \mathrm{T}}{T_{0} T}$ & $\begin{array}{c}\mathrm{T}_{\text {pred }}, \\
{ }^{\circ} \mathrm{C}\end{array}$ \\
\hline 0 & 0.0000 & 7.1 & 1.036 & 0 & 7.1 & 1.036 & 0 & 7.1 \\
\hline 1 & 0.0062 & 6.4 & 1.036 & 5.72184E-06 & 6.6 & 1.562 & 5.72184E-06 & 6.4 \\
\hline 2 & 0.0125 & 5.9 & 1.036 & $1.13631 \mathrm{E}-05$ & 6.2 & 1.350 & 1.13631E-05 & 5.9 \\
\hline 3.5 & 0.0221 & 5 & 1.036 & $1.97746 \mathrm{E}-05$ & 5.5 & 1.362 & $1.97746 \mathrm{E}-05$ & 5.0 \\
\hline 5 & 0.0319 & 4.4 & 1.036 & $2.828 \mathrm{E}-05$ & 4.8 & 1.227 & $2.828 \mathrm{E}-05$ & 4.4 \\
\hline 8 & 0.0522 & 2.4 & 1.036 & 4.63777E-05 & 3.4 & 1.312 & 4.63777E-05 & 2.4 \\
\hline 10 & 0.0662 & 0.9 & 1.036 & $6.00107 \mathrm{E}-05$ & 2.3 & 1.345 & 6.00107E-05 & 0.9 \\
\hline 12 & 0.0806 & -0.7 & 1.036 & $7.56778 \mathrm{E}-05$ & 1.1 & 1.350 & 7.56778E-05 & -0.7 \\
\hline 14 & 0.0955 & -1.8 & 1.036 & $9.41771 \mathrm{E}-05$ & -0.4 & 1.243 & $9.41771 \mathrm{E}-05$ & -1.8 \\
\hline 16 & 0.1108 & -3.3 & 1.036 & 0.000116441 & -2.1 & 1.181 & 0.000116441 & -3.3 \\
\hline 18 & 0.1267 & -5.3 & 1.036 & 0.000143558 & -4.1 & 1.151 & 0.000143558 & -5.3 \\
\hline 20 & 0.1430 & -7.8 & 1.036 & 0.000176795 & -6.6 & 1.133 & 0.000176795 & -7.8 \\
\hline 22 & 0.1599 & -10.2 & 1.036 & 0.000217627 & -9.6 & 1.079 & 0.000217627 & -10.2 \\
\hline \multirow[t]{2}{*}{23} & 0.1685 & -11.3 & 1.036 & 0.000241416 & -11.3 & 1.039 & 0.000241416 & -11.3 \\
\hline & & & & AAD & 0.8 & & AAD & 0.0 \\
\hline
\end{tabular}

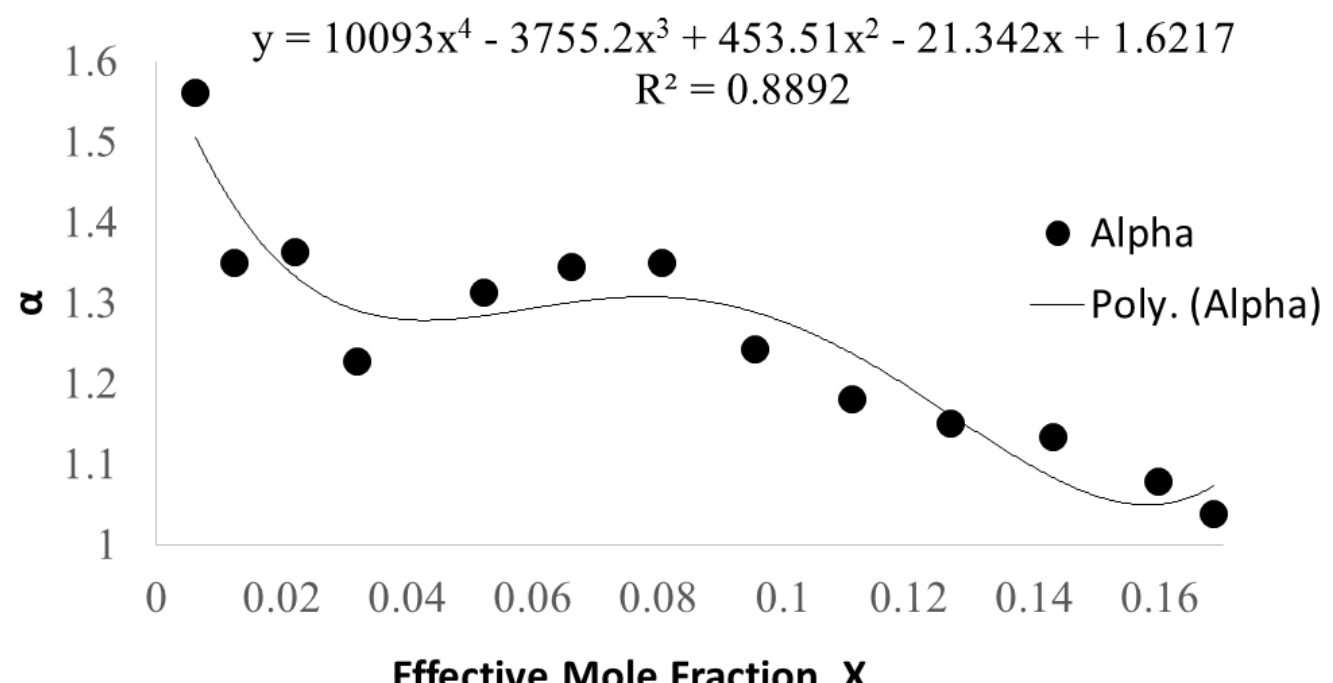

Figure A2. $\alpha$ vs. effective mole fraction 


\section{APPENDIX III. HLS approach compared to former system ${ }^{26}$}

Predicted results present a higher $\mathrm{AAD}$ than $\mathrm{ABOC}$ method. However, to fit $C_{1}, C_{2}$ and $C_{3}$ parameters, data from $\left\{\right.$ water $\left.+\mathrm{MgCl}_{2}\right\}$ solutions were also considered. Since there is a deviation from the standard behavior $\left(\frac{\Delta \mathrm{T}}{T_{0} T}=f(X)\right)$, it is probable that the use of such data lead to worse simulation results for $\mathrm{NaCl}, \mathrm{KCl}$, or $\mathrm{CaCl} 2$ salts.

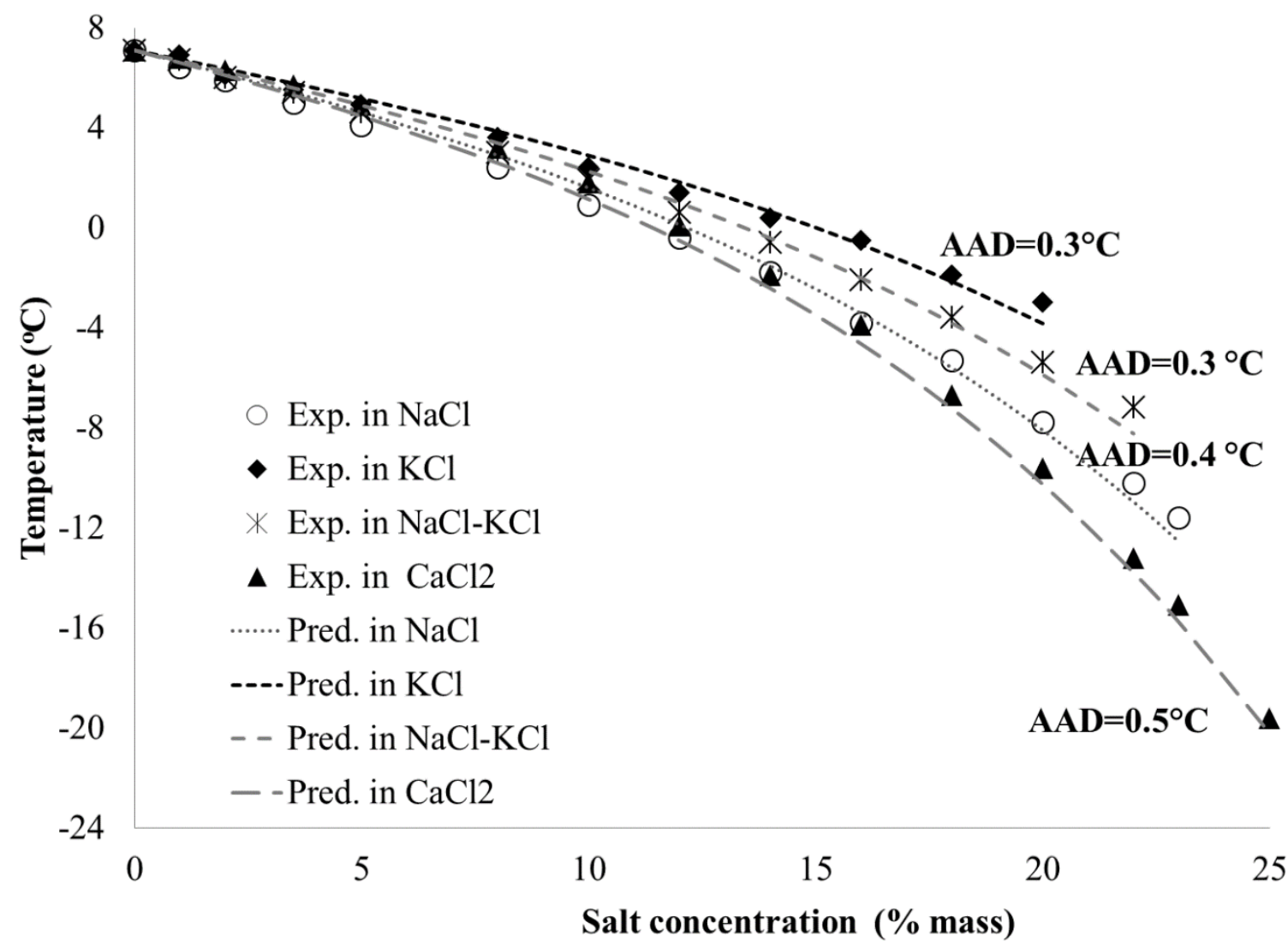

Figure A3. Experimental and predicted dissociation temperature of $\mathrm{CPH}$ in the presence of salts according to HLS approach for the four brine solutions from Ho-Van $e t a l^{26}$

\section{Literature Cited}

(1) Sloan ED, Koh CA. Clathrate Hydrate of Natural Gases. 3rd ed. CRC Press, FL: Boca Raton, 2008.

(2) Babu P, Linga P, Kumar R, Englezos P. A review of the hydrate based gas separation (HBGS) process forcarbon dioxide pre-combustion capture. Energy. 2015;85:261-279. doi:10.1016/j.energy.2015.03.103.

(3) Ho LC, Babu P, Kumar R, Linga P. HBGS (hydrate based gas separation) process for 
carbon dioxide capture employing an unstirred reactor with cyclopentane. Energy. 2013;63:252-259. doi:10.1016/j.energy.2013.10.031.

(4) Burnol A, Thinon I, Ruffine L, Herri JM. Influence of impurities (nitrogen and methane) on the $\mathrm{CO} 2$ storage capacity as sediment-hosted gas hydrates - Application in the area of the Celtic Sea and the Bay of Biscay. Int J Greenh Gas Control. 2015;35:96-109. doi:10.1016/j.ijggc.2015.01.018.

(5) Taheri Z, Shabani MR, Nazari K, Mehdizaheh A. Natural gas transportation and storage by hydrate technology: Iran case study. J Nat Gas Sci Eng. 2014;21:846-849. doi:10.1016/j.jngse.2014.09.026.

(6) Douzet J, Kwaterski M, Lallemand A, Chauvy F, Flick D, Herri JM. Prototyping of a real size air-conditioning system using a tetra-n-butylammonium bromide semiclathrate hydrate slurry as secondary two-phase refrigerant - Experimental investigations and modelling. Int J Refrig. 2013;36(6):1616-1631. doi:10.1016/j.jjrefrig.2013.04.015.

(7) Darbouret M, Cournil M, Herri JM. Rheological study of TBAB hydrate slurries as secondary two-phase refrigerants. Int J Refrig. 2005;28(5):663-671. doi:10.1016/j.jirefrig.2005.01.002.

(8) Ogoshi H, Takao S. Air-Conditioning System Using Clathrate Hydrate Slurry. JFE Tech Rep. 2004;3(3):1-5.

(9) Duc NH, Chauvy F, Herri JM. CO2 capture by hydrate crystallization - A potential solution for gas emission of steelmaking industry. Energy Convers Manag. 2007;48(4):1313-1322. doi:10.1016/j.enconman.2006.09.024.

(10) Li S, Fan S, Wang J, Lang X, Wang Y. Clathrate hydrate capture of CO2 from simulated flue gas with cyclopentane/water emulsion. Chinese J Chem Eng. 2010;18(2):202-206. doi:10.1016/S1004-9541(08)60343-2.

(11) Englezos P. Clathrate Hydrates. Ind Eng Chem Res. 1993;32:1251-1274. doi:10.1021/ie00019a001.

(12) Javanmardi J, Moshfeghian M. Energy consumption and economic evaluation of water desalination by hydrate phenomenon. Appl Therm Eng. 2003;23(7):845-857. doi:10.1016/S1359-4311(03)00023-1.

(13) Park K nam, Hong SY, Lee JW, et al. A new apparatus for seawater desalination by gas hydrate process and removal characteristics of dissolved minerals $\left(\mathrm{Na}^{+}, \mathrm{Mg}^{2+}, \mathrm{Ca}^{2+}, \mathrm{K}^{+}\right.$, $\left.\mathrm{B}^{3+}\right)$. Desalination. 2011;274(1-3):91-96. doi:10.1016/j.desal.2011.01.084. 
(14) Lee H, Ryu H, Lim J-H, Kim J-O, Dong Lee J, Kim S. An optimal design approach of gas hydrate and reverse osmosis hybrid system for seawater desalination. Desalin Water Treat. 2016;57(19):9009-9017. doi:10.1080/19443994.2015.1049405.

(15) He T, Nair SK, Babu P, Linga P, Karimi IA. A novel conceptual design of hydrate based desalination (HyDesal) process by utilizing LNG cold energy. Appl Energy. 2018;222(March):13-24. doi:10.1016/j.apenergy.2018.04.006.

(16) Babu P, Nambiar A, He T. A Review of Clathrate Hydrate Based Desalination to Strengthen Energy-Water Nexus. ACS Sustain Chem Eng. 2018. doi:10.1021/acssuschemeng.8b01616.

(17) Xu H, Khan MN, Peters CJ, Sloan ED, Koh CA. Hydrate-Based Desalination Using Cyclopentane Hydrates at Atmospheric Pressure. J Chem Eng Data. 2018:acs.jced.7b00815. doi:10.1021/acs.jced.7b00815.

(18) Subramani A, Jacangelo JG. Emerging desalination technologies for water treatment: A critical review. Water Res. 2015;75:164-187. doi:10.1016/j.watres.2015.02.032.

(19) Colten SL, Lin FS, Tsao TC, Stern SA, Barduhn AJ. Hydrolysis losses in the hydrate desalination process: rate measurements and economic analysis. Desalination. 1972;11(1):31-59. doi:10.1016/S0011-9164(00)84047-3.

(20) Sugi J, Saito S. Concentration and demineralization of sea water by the hydrate process. Desalination. 1967;3(1):27-31. doi:10.1016/S0011-9164(00)84021-7.

(21) R.A. McCormack, N.G. A. Build and operate clathrate desalination pilot plant, U.S. Dept. of the Interior, Bureau of Reclamation, 1998.

(22) R.A. McCormack, R.K. Andersen, Clathrate desalination plant preliminary research study, U.S. Dept. of the Interior, Bureau of Reclamation, 1995.

(23) R.W. Bradshaw, D.E. Dedrick, B.A. Simmons, J.A. Great- house, R.T. Cygan, E.H. Majzoub, Desalination Utilizing Clathrate Hydrates, Sandia National Laboratories, California, 2008.

(24) M.D. Max, Hydrate desalination for water purification, US 6991722 B2, 2006.

(25) Englezos P. The Freeze Concentration Process and its Applications. Dev Chem Eng Miner Process. 1994;2(1):3-15. doi:10.1002/apj.5500020102.

(26) Ho-Van S, Bouillot B, Douzet J, Maghsoodloo S, Herri J-M. Experimental Measurement and Thermodynamic Modeling of Cyclopentane Hydrates with $\mathrm{NaCl}, \mathrm{KCl}, \mathrm{CaCl} 2$ or $\mathrm{NaCl}$ KCl Present. Am Inst Chem Eng J. 2017. doi:10.1002/aic.16067. 
(27) Corak D, Barth T, Høiland S, Skodvin T, Larsen R, Skjetne T. Effect of subcooling and amount of hydrate former on formation of cyclopentane hydrates in brine. Desalination. 2011;278(1-3):268-274. doi:10.1016/j.desal.2011.05.035.

(28) Han S, Shin JY, Rhee YW, Kang SP. Enhanced efficiency of salt removal from brine for cyclopentane hydrates by washing, centrifuging, and sweating. Desalination. 2014;354:1722. doi:10.1016/j.desal.2014.09.023.

(29) Han S, Rhee YW, Kang SP. Investigation of salt removal using cyclopentane hydrate formation and washing treatment for seawater desalination. Desalination. 2017;404:132137. doi:10.1016/j.desal.2016.11.016.

(30) Cai L. Desalination via formation of binary clathrate hydrates. Ph.D.Thesis, Princeton University, New Jersey, 2016.

(31) Lv Y-N, Wang S-S, Sun C-Y, Gong J, Chen G-J. Desalination by forming hydrate from brine in cyclopentane dispersion system. Desalination. 2017;413:217-222. doi:10.1016/j.desal.2017.03.025.

(32) McAuliffe C. Solubility in Water of Paraffin, Cycloparaffin, Olefin, Acetylene, Cycloolefin, and Aromatic Hydrocarbons1. J Phys Chem. 1966;70(4):1267-1275. doi:DOI: 10.1021/j100876a049.

(33) Dean JA. LANGE'S HANDBOOK OF CHEMISTRY. Mater Manuf Process. 1990;5(4):687-688. doi:10.1080/10426919008953291.

(34) Han $\mathrm{H}$, Dong $\mathrm{O}$, Li D, Zeng D. Phase diagram of the $\mathrm{NaCl}-\mathrm{MgCl} 2-\mathrm{H} 2 \mathrm{O}$ system at 25$75^{\circ} \mathrm{C}$ and its application for $\mathrm{MgCl} 2 \cdot 6 \mathrm{H} 2 \mathrm{O}$ purification. Russ $J$ Phys Chem A. 2017;91(7):1255-1259. doi:10.1134/S0036024417070147.

(35) Huang Q, Lu G, Wang J, Yu J. Thermal decomposition mechanisms of $\mathrm{MgCl} 2 \cdot 6 \mathrm{H} 2 \mathrm{O}$ and MgCl2·H2O. J Anal Appl Pyrolysis. 2011;91(1):159-164. doi:10.1016/j.jaap.2011.02.005.

(36) Sloan D, Koh CA, Sum AK. Natural Gas Hydrate in Flow Assurance. Gulf Professional Pub./Elsevier; 2011.

(37) Sabil KM, Román VR, Witkamp GJ, Peters CJ. Experimental observations on the competing effect of tetrahydrofuran and an electrolyte and the strength of hydrate inhibition among metal halides in mixed $\mathrm{CO}_{2}$ hydrate equilibria. J Chem Thermodyn. 2010;42(3):400-408. doi:10.1016/j.jct.2009.09.012.

(38) Cha M, Hu Y, Sum AK. Methane hydrate phase equilibria for systems containing $\mathrm{NaCl}$, KCl, and $\mathrm{NH}_{4}$ Cl. Fluid Phase Equilib. 2016;413:2-9. doi:10.1016/j.fluid.2015.08.010. 
(39) Wells RC. Sodium sunphate: its sources and uses. United States Geol Surv. 1923.

(40) Hildebrand JH, Scott RL. Regular Solutions. Prentice-Hall, NJ: Englewood Cliffs, 1962

(41) Miyawaki O, Saito A, Matsuo T, Nakamura K. Activity and activity coefficient of water in aqueous solutions and their relationships with solution structure parameters. Biosci Biotechnol Biochem. 1997;61(3):466-469. doi:10.1271/bbb.61.466.

(42) $\mathrm{Hu} \mathrm{Y,} \mathrm{Lee} \mathrm{BR,} \mathrm{Sum} \mathrm{AK.} \mathrm{Universal} \mathrm{correlation} \mathrm{for} \mathrm{gas} \mathrm{hydrates} \mathrm{suppression} \mathrm{temperature} \mathrm{of}$ inhibited systems: I. Single salts. AIChE J. July 2017. doi:10.1002/aic.15846.

(43) $\mathrm{Hu} \mathrm{Y,} \mathrm{Lee} \mathrm{BR,} \mathrm{Sum} \mathrm{AK.} \mathrm{Universal} \mathrm{correlation} \mathrm{for} \mathrm{gas} \mathrm{hydrates} \mathrm{suppression} \mathrm{temperature} \mathrm{of}$ inhibited systems: II. Mixed salts and structure type. AIChE J. 2018;64(6):2240-2250. doi:10.1002/aic.16116.

(44) van der Waals JH, Platteeuw JC. Clathrate solutions. Adv Chem Phys. 1958;2:1-57. doi:10.1002/9780470143483.ch1.

(45) Nakajima M, Ohinura R, Mori YH. Clathrate hydrate formation from cyclopentane-inwater emulsions. Ind Eng Chem Res. 2008;47(22):8933-8939. doi:10.1021/ie800949k.

(46) Parkhurst, D.L., Appelo, C.A.J., 1999. User's guide to PHREEQC (version 2) - a computer program for speciation, batchreaction, one-dimensional transport, and inverse geochemical calculations, Water-Resour. Invest. Rep. 99-4259. US Geol. Surv. Denver, Colorado.

(47) A. Pieroen. Gas hydrates - approximate relations betvveen heat. Recl des Trav Chim des Pays-Bas. 1955;74:995-1002.

(48) Herri J-M, Bouchemoua A, Kwaterski M, Fezoua A, Ouabbas Y, Cameirao A. Gas hydrate equilibria for $\mathrm{CO} 2-\mathrm{N} 2$ and $\mathrm{CO} 2-\mathrm{CH} 4$ gas mixtures-Experimental studies and thermodynamic modelling. Fluid Phase Equilib. 2011;301(2):171-190. doi:10.1016/j.fluid.2010.09.041.

(49) Parrishl WR, John M. Dissociation Pressures of Gas Hydrates Formed by Gas Mixtures. Ind Eng Chem Process Des Dev. 1972;11(1):26-35. doi:10.1021/i260041a006. 
For Table of Contents Use Only

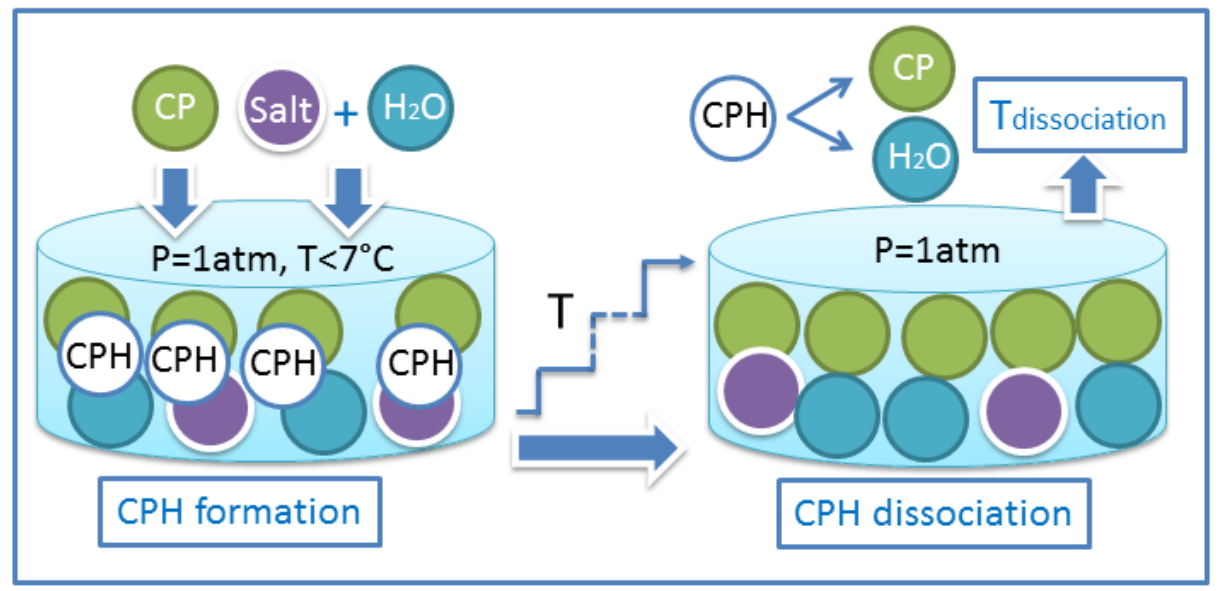

